\title{
Quantifying the role of fire in the Earth system - Part 2: Impact on the net carbon balance of global terrestrial ecosystems for the 20th century
}

\author{
F. Li ${ }^{1}$, B. Bond-Lamberty ${ }^{2}$, and S. Levis ${ }^{3}$ \\ ${ }^{1}$ International Center for Climate and Environmental Sciences, Institute of Atmospheric Physics, Chinese Academy of \\ Sciences, Beijing, China \\ ${ }^{2}$ Pacific Northwest National Laboratory, Joint Global Change Research Institute, University of Maryland, College Park, \\ Maryland, USA \\ ${ }^{3}$ Terrestrial Sciences Section, Climate and Global Dynamics Division, National Center for Atmospheric Research, Boulder, \\ Colorado, USA \\ Correspondence to: F. Li (lifang@mail.iap.ac.cn)
}

Received: 22 October 2013 - Published in Biogeosciences Discuss.: 4 November 2013

Revised: 22 January 2014 - Accepted: 3 February 2014 - Published: 7 March 2014

\begin{abstract}
Fire is the primary form of terrestrial ecosystem disturbance on a global scale. It affects the net carbon balance of terrestrial ecosystems by emitting carbon directly and immediately into the atmosphere from biomass burning (the fire direct effect), and by changing net ecosystem productivity and land-use carbon loss in post-fire regions due to biomass burning and fire-induced vegetation mortality (the fire indirect effect). Here, we provide the first quantitative assessment of the impact of fire on the net carbon balance of global terrestrial ecosystems during the 20th century, and investigate the roles of fire's direct and indirect effects. This is done by quantifying the difference between the 20th century fire-on and fire-off simulations with the NCAR Community Land Model CLM4.5 (prescribed vegetation cover and uncoupled from the atmospheric model) as a model platform. Results show that fire decreases the net carbon gain of global terrestrial ecosystems by $1.0 \mathrm{Pg} \mathrm{Cyr}^{-1}$ averaged across the 20th century, as a result of the fire direct effect $\left(1.9 \mathrm{Pg} \mathrm{C} \mathrm{yr}^{-1}\right)$ partly offset by the indirect effect $\left(-0.9 \mathrm{Pg} \mathrm{C} \mathrm{yr}^{-1}\right)$. Post-fire regions generally experience decreased carbon gains, which is significant over tropical savannas and some North American and East Asian forests. This decrease is due to the direct effect usually exceeding the indirect effect, while they have similar spatial patterns and opposite sign. The effect of fire on the net carbon balance significantly declines until $\sim 1970$ with a trend of $8 \mathrm{Tg} \mathrm{C} \mathrm{yr}^{-1}$ due to an increasing indirect ef-
\end{abstract}

fect, and increases subsequently with a trend of $18{\mathrm{Tg} \mathrm{C} \mathrm{yr}^{-1}}^{-1}$ due to an increasing direct effect. These results help constrain the global-scale dynamics of fire and the terrestrial carbon cycle.

\section{Introduction}

Fire is an important earth system process and the primary terrestrial ecosystem disturbance agent on a global scale (Fosberg et al., 1999; Bowman et al., 2009). Today, global fires are routinely monitored by satellite (Arino and Rosaz, 1999; Giglio et al., 2003; Roy et al., 2005) and are simulated by most of the global terrestrial biosphere models used for the Intergovernmental Panel on Climate Change (IPCC) (Arora and Boer, 2005; Thonicke et al., 2010; Li et al., 2012). Fire affects the net carbon balance of terrestrial ecosystems both directly and indirectly (Kasischke et al, 1995; Mouillot and Field, 2005). The direct effect is caused by biomass burning, which emits carbon into the atmosphere immediately (Andreae and Merlet, 2001; van der Werf et al., 2010). In addition, fire can affect net ecosystem productivity (NEP, the balance of ecosystem productivity and respiration) and landuse carbon loss in post-fire regions by changing vegetation and carbon pool structures or terrestrial physical characteristics through biomass burning and vegetation mortality, which 
is not limited to the burning period and can last for more than $100 \mathrm{yr}$ in some regions (the indirect effect, Kasischke et al., 1995; Houghton et al., 1999; Hicke et al., 2003; Amiro et al., 2010). Quantifying the impact of fire on the global terrestrial carbon balance is an important part of quantifying the role of fire in the Earth system, and is required to better understand the global-scale carbon dynamics and ecosystems and their changes (Mouillot and Field, 2005; Schulze, 2006; Running, 2008).

Earlier global-scale quantitative studies about the effect of fire on terrestrial carbon balance were focused on the fire carbon emissions (i.e., the fire direct effect). Quantitative assessments of contemporary global fire carbon emissions were pioneered by Seiler and Crutzen (1980) using information documented in the literature. Subsequently, Schultz (2002), Duncan et al. (2003), van der Werf et al. (2006, 2010), and Randerson et al. (2012) improved our understanding of the spatial and temporal distribution of contemporary fire carbon emissions using satellite observations, providing an estimate of $\sim 2 \mathrm{Pg} \mathrm{C} \mathrm{yr}^{-1}$ for global fire carbon emissions during the satellite era. Moreover, Prentice et al. (2011) pointed out that fire carbon emissions from the satellite-based GFED3 and the LPX-DGVM global dynamical vegetation model accounted for about $1 / 3$ and $1 / 5$ of the interannual variation of the 1997-2005 global carbon balance, respectively, by calculating the determinant coefficients (i.e., $R^{2}$ values in the linear regression) between detrended fire carbon emissions and global carbon balance. Besides improving contemporary estimates, long-term fire carbon emissions over the past several decades, centuries, and millennia have been reconstructed based on global models with carbon dynamics (Mouillot et al., 2006; Schultz et al., 2008; Kloster et al., 2010; Ward et al., 2012; van der Werf et al., 2013), the fire emissions equation from Seiler and Crutzen (1980) with estimated historical global burned areas as input data (Mieville et al., 2010), sedimentary charcoal records (Marlon et al., 2008, 2013), Antarctic ice-core $\mathrm{CH}_{4}$ records (Ferretti et al., 2005), and Antarctic ice-core CO records (Wang et al., 2010; Prentice, 2010). Large uncertainties remain, however.

Almost all the earlier studies regarding the total and indirect effects of fire were on a site or regional scale. Using boreal forest chronosequences, Law et al. (2003), Campbell et al. (2004), Bond-Lamberty et al. (2004), Goulden et al. (2006), Amiro et al. (2010), and Goulden et al. (2011) investigated the changes in site-level NEP and/or its components in the post-fire succession period. Also, several studies estimated the effect of fire on the terrestrial carbon fluxes at the site level or in a region using an empirical model (Kasischke et al., 1995; Houghton et al., 2000), the BiomeBGC biogeochemical model (Thornton et al., 2002; BondLamberty et al., 2007), the CASA carbon cycle model (Hicke et al., 2003), a simplified satellite-based carbon flux model (Yi et al., 2013), and the ORCHIDEE global process-based vegetation model with vegetation distribution fixed (Yue et al., 2013). In addition, using field observations, San Jose et al. (1998), Shackleton and Scholes (2000), Tilman et al. (2000), Wang et al. (2001), and Irvine et al. (2007) investigated the differences in site-level ecosystem carbon storage and/or fluxes with different fire frequencies or severities. As far as we know, Ward et al. (2012) were the only ones to provide a global estimate involving the indirect effect of fire, which showed that fire decreased the carbon loss from land use and land cover change (wood harvest included) based on an unreleased version of the Community Land Model CLM4. So far, there have not been any global estimates of fire total effect and the effect of fire on terrestrial carbon balance through changing NEP.

Recently, Li et al. (2012a, b, 2013) developed a global fire model. In this fire model, the burned area fraction was determined by climate and weather conditions, vegetation composition and structure, and human activities. After the calculation of the burned area fraction, the fire impact was estimated, including biomass and peat burning, fire-induced vegetation mortality, and the adjustment of the carbon and nitrogen $(\mathrm{C} / \mathrm{N})$ pools. As part 1 of a project designed to quantify the role of fire in the Earth system (Li et al., 2013), the global fire scheme was introduced in detail, tested in the Community Earth System Model version 1.0 (CESM1.0)'s land component the Community Land Model version 4 (CLM4), and evaluated against the satellite-based GFED3 fire product for 1997-2004. Results showed that the fire scheme reasonably simulated the multi-year average of burned areas, fire seasonality, fire interannual variability, and fire carbon emissions. In addition, simulated contributions of contemporary fire carbon emissions from various sources (deforestation fires, agricultural fires, peat fires, and others) were close to previous assessments based on satellite data, government statistics, and other information. The CLM4.5 global land model (Oleson et al., 2013), available at http://www.cesm.ucar.edu/models/ cesm1.2 since June 2013, included the new fire model and calculated the water, energy, carbon, and nitrogen cycles and their interactions at the land-atmosphere interface, providing a practical platform to quantify the long-term effect of fire on the global net terrestrial carbon balance.

As part 2 of the project designed to quantify the role of fire in the Earth system, the present study provides the first estimates regarding the impact of fire on the global net terrestrial carbon balance during the 20th century. It is based on quantitative assessment of the difference in carbon fluxes between a CLM4.5 control (fire-on) simulation and a 20th century fire-off simulation. Related mechanisms are investigated by analyzing the role of fire's direct and indirect effects. In this paper, Sect. 2 introduces the methods and data, including the model platform, simulations and model input data, evaluation of CLM4.5 contemporary global simulations and related benchmark data, and CLM4.5 burned area simulations during the 20th century. Section 3 quantifies the impact of fire on net ecosystem exchange (NEE) during the 20th century and then investigates the role of fire direct and indirect effects, where NEE is used by CLM4.5 to quantify the net 
carbon balance of terrestrial ecosystems (see Sect. 2.1). Discussion and conclusions appear in Sect. 4.

\section{Methods and data}

\subsection{Model platform}

CLM4.5 is the latest version of the CLM family of models (Oleson et al., 2013) and the land component of the CESM1.2 earth system model. The CLM family has been widely used to investigate the long-term historical change in carbon, water, heat fluxes and fire (Qian et al., 2006; Bonan and Levis, 2010; Lawrence et al., 2012; Kloster et al., 2010; Le Quéré et al., 2013; Koven et al, 2013; Ward et al., 2013), and, as the land component of CESM and its precursor the Community Climate System Model (CCSM), supports the IPCC global change research (http://www.ipcc.ch/). CLM4.5, like its precursor CLM4, integrates biophysical, biogeographic, and biogeochemical processes of the land surface into a single and physically consistent framework, and has the ability to model the impact of transient land cover and land use change. It succeeds CLM4, whose biogeochemistry module is mainly based on terrestrial ecosystem model Biome-BGC version 4.1.2 (Thornton et al., 2007), with updates to photosynthesis (Bonan et al., 2011; Sun et al., 2012), soil biogeochemistry (Koven et al., 2013), fire dynamics (Li et al., 2012a, b, 2013), cold region hydrology (Swenson et al., 2012; Swenson and Lawrence, 2012), the lake model (Subin et al., 2012), and the biogenic volatile organic compounds model (Guenther et al., 2012). Like its precursors, CLM4.5 represents the land surface as a hierarchy of subgrid types, including glacier, lake, wetland, urban, and vegetation land units. A vegetated land unit is further divided into plant function types (PFTs) that share a soil column.

The terrestrial carbon cycle in CLM4.5 is initiated by biosphere carbon uptake via photosynthesis (gross primary production, GPP). GPP and a storage carbon pool supply carbon for the metabolic costs of live leaves, stems, and roots (i.e., maintenance respiration). After accounting for the carbon cost of maintenance respiration, the remaining carbon flux is allocated to the carbon pools of live vegetation tissues for current plant growth and the storage carbon pools for future growth and metabolic activities. The process of plant growth produces growth respiration flux. GPP minus autotrophic respiration ( $\mathrm{Ra}$, the sum of maintenance respiration and growth respiration) is called the net primary productivity $(\mathrm{NPP}=\mathrm{GPP}-\mathrm{Ra})$. A portion of the carbon pools from live vegetation tissues is transferred to litter by turnover, mortality (including fire-induced mortality), and phenology processes. Before the decomposition of litter, woody litter passes through a coarse woody debris (CWD) pool for physical degradation. A portion of the carbon is released into the atmosphere during the decomposition of litter and soil organic matter, which is called heterotrophic respiration $(\mathrm{Rh})$.
Finally, the net carbon balance of terrestrial ecosystems (i.e., NEE) is the balance between the net ecosystem productivity (i.e., NEP $=\mathrm{NPP}-\mathrm{Rh}$ ) and the carbon loss of terrestrial ecosystems due to biomass burning $\left(C_{\mathrm{fe}}\right)$ and land use $\left(C_{\mathrm{lh}}\right.$, wood harvest included):

$\mathrm{NEE}=-\mathrm{NEP}+C_{\mathrm{fe}}+C_{\mathrm{lh}}$.

A negative value of NEE indicates a land uptake of carbon. Note that the definition of NEP in CLM4.5 is the same as that in Campbell et al. (2004) and LPJ-DGVM (Sitch et al., 2003), but differs from the eddy covariance-oriented definition in Randerson et al. (2002). The definition of NEE in CLM4.5 is the same as that in LPJ-DGVM (Sitch et al., 2003), but the latter lacks the item of $C_{\mathrm{lh}}$ because LPJDGVM does not consider the land use and wood harvest.

The fire module in CLM4.5 (Li et al. 2012a, b, 2013; Oleson et al., 2013) includes four components: agricultural fires in cropland, deforestation fires in the tropical closed forests, non-peat fires outside cropland and tropical closed forests, and peat fires. For agricultural fires, the burned area fraction is determined by fuel load, socioeconomic factors, prescribed seasonality of agricultural fires, and fractional coverage of cropland. The burned area fraction due to deforestation fires in the tropical closed forests is determined by deforestation rate and weather and climate conditions. Non-peat fires outside croplands and tropical closed forests are calculated by a process-based fire model of intermediate complexity. The burned area fraction is affected by climate and weather conditions, vegetation composition and structure, and human activities represented by non-linear functions of population density and economic situations. The burned area fraction due to peat fires depends on climate conditions and fractional coverage of unsaturated peatland. After the calculation of column-level burned area fraction, fire impact is estimated based on a column-level or converted PFT-level burned area, including biomass and peat burning, fire-induced vegetation mortality, and the adjustment of the carbon and nitrogen pools. Fire carbon/nitrogen $(\mathrm{C} / \mathrm{N})$ emissions due to biomass burning are the product of live and dead $\mathrm{C} / \mathrm{N}$ pools and combustion completeness factors (CCs). In the CLM4.5 official version, CCs for column-level litter and CWD are set to be 0.4 and 0.2 , respectively. PFT-dependent CCs are listed in Table S1. Fire-related vegetation mortality leads to $\mathrm{C} / \mathrm{N}$ transfer among $\mathrm{C} / \mathrm{N}$ pools: a fraction of $\mathrm{C} / \mathrm{N}$ from uncombusted live tissues is transferred to litter pools; a fraction of $\mathrm{C} / \mathrm{N}$ from uncombusted live stems is transferred to dead stems. These fractions are defined as the PFT-dependent fire mortality factors (Table S1).

The CLM4.5 official version (clm4_5_07) with several modifications in the fire module is used here. First, two bugs in the code are fixed: one is in modeling fire in tropical closed forests when land use and the land cover change data set is not used (e.g., spin-up simulation), and the other is in the conversion of the burned area fraction from column level to PFT level in grid cells with a fraction of cropland. Second, 
we change the CC from 0.2 to 0.25 for CWD and from 0.4 to 0.5 for litter, and set the maximum spread rate for grasses $5 \%$ higher than the original value. When we tuned parameters for the CLM4.5 official version based on a $1.9^{\circ}$ (lat) $\times 2.5^{\circ}$ (lon) simulation, the 1850 spin-up simulation was stopped too early and a slight downward trend was still present in the fire simulation. This and the first bug caused a high bias of burned area and especially fire carbon emissions in forests for the 1850-2004 simulation, which misled us into setting lower CCs for CWD and litter and a bit lower maximum spread rate for grasses in the CLM4.5 official version. The adjusted CC for litter is close to that $(\sim 0.6)$ used in CLM4 by Kloster et al. (2010) and Li et al. (2013). The adjusted CC for CWD is about half of $\sim 0.6$ used by Kloster et al. (2010) and 0.5 used by Li et al. (2013) in CLM4, because we have found that CWD simulated in CLM4.5 is double that in CLM4. Third, we change the lower threshold of the fuel load to $75 \mathrm{~g} \mathrm{C} \mathrm{m}^{-2}$ and set the higher threshold of the impact of surface relative humidity (RH) on fire to $80 \%$, but keep the higher threshold of the fuel load of $1050 \mathrm{~g} \mathrm{C} \mathrm{m}^{-2}$ and the lower threshold of the RH impact of $30 \%$ unchanged, in order to decrease the impact of spatial resolution on fire simulation in savannas. The two adjusted parameter values can be supported by William et al. (1998) and Weir (2007). Fourth, due to the above changes (mainly from the second bug fixing), a global constant that controls the global agricultural burned area is recalibrated by the inverse method introduced in $\mathrm{Li}$ et al. (2013) and is changed from $0.153(30 \mathrm{~min})^{-1}$ to $0.148(30 \mathrm{~min})^{-1}$. The revised fire code can be obtained from us for free.

\subsection{Simulations and input data}

\subsubsection{Control (fire-on) and fire-off simulations}

All simulations are conducted using CLM4.5 with prescribed vegetation cover and uncoupled from the atmospheric model at a spatial resolution of $1.9^{\circ}$ (lat) $\times 2.5^{\circ}$ (lon) and a temporal resolution of $30 \mathrm{~min}$.

First, a control simulation (i.e., fire-on simulation) is performed for 1850-2004. The 1850-2004 transient run is forced by the 1850-2004 time-varying $\mathrm{CO}_{2}$ concentration, nitrogen and aerosol deposition, land-use and land cover change, and population density data. Atmospheric forcing is obtained by cycling 25-yr (1948-1972) atmospheric reanalysis data (Qian et al., 2006) of surface temperature, wind speed, specific humidity, air pressure, precipitation, and surface downward solar radiation for 1850-1947 followed by the full time series of the 1948-2004 reanalysis data, and using climatological cloud-to-ground lightning data before 1996 and time-varying cloud-to-ground lightning data for 1996-2004. The 1850-2004 transient run starts from an 1850 equilibrium (spun-up) state of CLM4.5 that is forced by the cycling 25-,yr (1948-1972) atmospheric reanalysis data from Qian et al. (2006), the climatological cloud-to-ground light- ning data, and the land cover, $\mathrm{CO}_{2}$ concentration, nitrogen and aerosol deposition, and population density at their 1850 values.

Second, a 20th century fire-off simulation is branched from the control simulation in 1900 . The only difference between fire-on and fire-off simulations is that the fire is switched off during 1900-1999 in the fire-off simulation. The difference between the fire-on and fire-off simulations represents the fire effect.

\subsubsection{Input data}

The 1948-2004 T62 $\left(\sim 1.875^{\circ}\right)$ global $3 \mathrm{~h}$ surface temperature, wind speed, specific humidity, air pressure and $6 \mathrm{~h}$ precipitation and surface downward solar radiation are from Qian et al. (2006). The 1850-2004 annual $0.5^{\circ}$ population density is derived from the Database of the Global Environment version 3.1 (HYDEv3.1) (Klein Goldewijk et al., 2010) prior to 1990 and the Gridded Population of the World version 3 (GPWv3) (CIESIN, 2005) after 1990. The climatological $3 \mathrm{~h} \mathrm{T62}$ cloud-to-ground lightning data is derived from the NASA LIS/OTD grid product v2.2 (http://ghrc. msfc.nasa.gov) $2 \mathrm{~h}$ climatological lightning data. The timevarying $3 \mathrm{~h}$ T62 cloud-to-ground lightning data for 19962004 is derived from the LIS/OTDv2.2 daily lightning time series and $2 \mathrm{~h}$ climatological lightning data. The cloud-toground lightning fraction is calculated based on Prentice and Mackerras (1977). The annual $1.9^{\circ}$ (lat) $\times 2.5^{\circ}$ (lon) land use and land cover change (LULCC) data for 1850-2005 are from the CLM4.5 land surface data (Lawrence et al., 2012; Oleson et al., 2013), which are based on version 1 of the Land-Use History A product (LUHa.v1) (Hurtt et al., 2006). The prescribed 1850-2004 annual $\mathrm{CO}_{2}$ and monthly $1.9^{\circ}$ (lat) $\times 2.5^{\circ}$ (lon) nitrogen and aerosol deposition are provided with CESM1.2, where the $\mathrm{CO}_{2}$ comes from observations, and the nitrogen and aerosol deposition come from simulations with the CESM atmospheric chemistry and transport model (Hurrel et al., 2013). Other standard data sets necessary for running CLM4.5 are described in Oleson et al. (2013). All of the input data are automatically regridded to the resolution of model running by CLM4.5.

\subsection{Evaluation of CLM4.5 contemporary global performance}

\subsubsection{Benchmarks}

Data used to evaluate the CLM4.5 global performance of the present-day burned area, fire carbon emissions, NEE, GPP, and NPP are introduced as follows.

As benchmarks for the global fire simulations, we use 1997-2004 $0.5^{\circ}$ monthly burned area and fire carbon emissions from the GFED3 (Giglio et al., 2010; van der Werf et al., 2010). GFED3 and its precursors have been commonly used to evaluate global fire simulations (Arora and Boer, 
2005; Kloster et al., 2010; Prentice et al., 2011; Ward et al., 2012; Li et al., 2012a, 2013). The GFED3 burned area data are a mixture of observations and satellite-based estimates, which are generated from the $500 \mathrm{~m}$ MODIS burned area maps (MCD64A1), active fire detections from multiple satellites, local regression, and regional regression trees (Giglio et al., 2010; L. Giglio, personal communication, 2012). The GFED3 fire carbon emissions data are the output of a revised version of CASA carbon model driven by the GFED3 burned area, the MODIS vegetation and land data, active fire detections from multiple satellites, atmospheric observations, the MODIS photosynthetically active radiation, and the AVHRR NDVI data (van der Werf et al., 2010).

As benchmarks for the global total of NEE, we use the 1990s average presented by the IPCC AR4 (Denman et al., 2007) and the IPCC AR5 (Ciais et al., 2013). As benchmarks for temporal variability of NEE, we use the 19882004 monthly $2.5^{\circ}$ (lat) $\times 3.75^{\circ}$ (lon) NEE data from the LSCE data (Chevallier et al., 2010) and 1982-2004 monthly $3.75^{\circ}$ (lat) $\times 5^{\circ}$ (lon) NEE data from the MPI-BGC Jena v3.5 data (Röedenbeck et al., 2006; updated in Mar. 2013). The two NEE data sets are based on the measured atmospheric $\mathrm{CO}_{2}$ concentrations and atmospheric transport models. Similar to Prentice et al. (2011), we only use the temporal variability of global fluxes, since it is the most reliable output of the inversion process, although the two inversions also provide global spatial distribution. As benchmarks for global GPP, we use the 2000-2004 $1 \mathrm{~km}$ annual GPP from collection 5 of the MODIS GPP product (MOD17) (Zhao et al., 2005; Zhao and Running et al., 2010), and 1982-2004 monthly $0.5^{\circ}$ GPP data derived from the FLUXNET network of eddy covariance towers (Jung et al., 2011; updated in Feb. 2013). The two global GPP products are commonly used to evaluate the global GPP simulation of process-based ecosystem models (Bonan et al., 2011; Mao et al., 2012; Piao et al., 2013). In addition, the 2000-2004 $1 \mathrm{~km}$ annual NPP from collection 5 of the MODIS NPP product (MOD17) (Zhao et al., 2005; Zhao and Running et al., 2010) is used as the benchmark for CLM4.5 NPP simulation.

\subsubsection{CLM4.5 global performance}

Testing the performance of global models against presentday observations is a crucial procedure, to enable confidence in the historical reconstructions, future projections, and quantitative assessments of the impact of a process or phenomenon. Table 1 summarizes the global performance of CLM4.5. As shown in Table 1, CLM4.5 can overall reasonably simulate the global total temporal variability and largescale spatial pattern of contemporary fire and terrestrial carbon fluxes.

For burned areas, the 1997-2004 average of the global total simulated in CLM4.5 is $322 \mathrm{Mhayr}^{-1}$, close to the

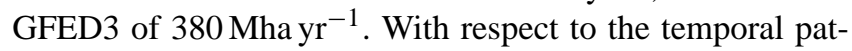
tern, CLM4.5 captures the peak in 1998 and the year-to-year variability from 1999-2003 shown in GFED3 (Fig. S1a). With respect to the spatial pattern of the 1997-2004 average, CLM4.5 reproduces a high burned area fraction in tropical savannas, a moderate fraction in northern Eurasia, and a low fraction in deserts and humid forests (Fig. S2). The temporal correlation between CLM4.5 and GFED3 global burned areas over 1997-2004 is 0.63 , and the global spatial correlation between the CLM4.5 and GFED3 1997-2004 average burned area fraction is 0.71 . Both of the temporal and spatial correlations can pass the student's t-test at the 0.05 significance level.

For fire carbon emissions, the simulated global total for the 1997-2004 average is $2.1 \mathrm{Pg} \mathrm{C} \mathrm{yr}^{-1}$, the same as GFED3. Interannual variability of global fire carbon emissions from CLM4.5 is similar to GFED3, i.e., peaks in 1997 and 1998 followed by a decline (Fig. S1b). For the 1997-2004 average, CLM4.5 reproduces high carbon emissions in tropical savannas, moderate emissions around $50^{\circ} \mathrm{N}$ in Eurasia, and low emissions in deserts and the core of tropical humid forests (Fig. S3). The spatiotemporal patterns of CLM4.5 and GFED3 are significantly correlated at the 0.05 level (temporal correlation of global fire carbon emissions: 0.91; global spatial correlation of 1997-2004 averaged fire carbon emissions: 0.5).

Global NEE simulated by CLM4.5 for the 1990s is $0.8 \mathrm{Pg} \mathrm{C} \mathrm{yr}^{-1}$, within the range of $-1.0 \pm 0.6$ reported by the IPCC AR4 (Denman et al., 2007) and $-1.1 \pm 0.9$ reported by the IPCC AR5 (Ciais et al., 2013). CLM4.5 can reproduce the amplitude and timing of peaks and troughs shown in the LSCE (Chevallier et al., 2010) and MPI-BGC Jena v3.5 (Röedenbeck et al., 2006, C. Röedenbeck, personal communication, 2013) (Fig. S4). Temporal correlation coefficients are 0.74 between the CLM4.5 simulation and LSCE for 1988-2004 and 0.75 between the CLM4.5 simulation and MPI-BGC Jena v3.5 for 1981-2004, significant at the 0.05 level.

Averages of the global GPP are 127 and $122 \mathrm{Pg} \mathrm{C} \mathrm{yr}^{-1}$ for CLM4.5 and the FLUXNET-based estimates (Jung et al., 2011; Martin Jung, personal communication, 2013) over 1982-2004; and 130, 110, and $122 \mathrm{Pg} \mathrm{C} \mathrm{yr}^{-1}$ for CLM4.5, the satellite-based estimates (Zhao et al., 2005; Zhao and Running et al., 2010), and the FLUXNET-based estimates over 2000-2004. CLM4.5's GPP is higher than the two benchmarks, but close to the multi-model ensemble average of the 1982-2008 global GPP across the 10 processbased terrestrial biosphere models used for the IPCC AR5 $\left(133 \pm 15 \mathrm{Pg} \mathrm{C} \mathrm{yr}^{-1}\right)$ (Piao et al., 2013). Temporal correlation between CLM4.5 and the FLUXNET-based estimates is 0.38 over 1982-2004, while temporal correlation with the FLUXNET-based estimates is $0.3-0.4$ for two models and less than 0.3 for the other eight models in Piao et al. (2013). For 2000-2004, the temporal correlation between CLM4.5 and the satellite-based estimates is 0.87 , significant at the 0.05 level and higher than 0.85 between the two benchmarks. Piao et al. (2013) pointed out that the FLUXNET- 
Table 1. Comparison between CLM4.5 simulations and benchmarks for burned area, fire carbon emissions, net ecosystem exchange (NEE, a negative value indicates a land uptake of carbon), gross primary production (GPP), and net primary production (NPP). Statistics include the average (Avg), temporal correlation of annual global total between CLM4.5 and benchmarks (T-Cor), and global spatial correlation of multi-year average between CLM4.5 and benchmarks with a spatial resolution of $1.9^{\circ}$ (lat) $\times 2.5^{\circ}$ (lon) (S-Cor) during the common periods

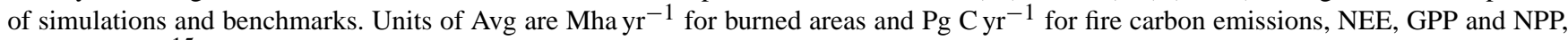
where $\mathrm{Pg}=10^{15} \mathrm{~g}$.

\begin{tabular}{|c|c|c|c|c|c|}
\hline Variables & Period & Statistics & CLM4.5 & Benchmarks & Source for benchmarks \\
\hline \multirow{3}{*}{$\begin{array}{l}\text { Burned } \\
\text { area }\end{array}$} & 1997-2004 & Avg & 322 & 380 & \multirow{6}{*}{$\begin{array}{l}\text { GFED3 (Giglio et al., 2010; } \\
\text { van der Werf et al., 2010) }\end{array}$} \\
\hline & & T-Cor & & $0.63^{\mathrm{b}}$ & \\
\hline & & S-Cor ${ }^{\mathrm{a}}$ & & $0.71^{\mathrm{b}}$ & \\
\hline \multirow{3}{*}{$\begin{array}{l}\text { Fire } \\
\text { carbon } \\
\text { emissions }\end{array}$} & 1997-2004 & Avg & 2.1 & 2.1 & \\
\hline & & T-Cor & & $0.91^{\mathrm{b}}$ & \\
\hline & & S-Cor & & $0.50^{\mathrm{b}}$ & \\
\hline \multirow[t]{4}{*}{ NEE } & $1990 \mathrm{~s}$ & Avg & -0.8 & $-1.0 \pm 0.6$ & IPCC AR4 (Denman et al., 2007) \\
\hline & & & & $-1.1 \pm 0.9$ & IPCC AR5 (Ciais et al., 2013) \\
\hline & 1988-2004 & T-Cor & & $0.74^{b}$ & LSCE (Chevallier et al., 2010) \\
\hline & 1981-2004 & T-Cor & & $0.75^{\mathrm{b}}$ & $\begin{array}{l}\text { MPI-BGC Jena v3.5 (Röedenbeck et al., 2006; } \\
\text { C. Röedenbeck, personal communication, 2013) }\end{array}$ \\
\hline \multirow[t]{6}{*}{ GPP } & 1982-2004 & Avg & 127 & 122 & Jung et al. (2011); M. Jung (personal \\
\hline & & T-Cor & & $0.38^{\mathrm{c}}$ & communication, 2013) \\
\hline & & S-Cor & & $0.90^{\mathrm{b}}$ & \\
\hline & 2000-2004 & Avg & 130 & 110 & \multirow{6}{*}{$\begin{array}{l}\text { Zhao et al. (2005); } \\
\text { Zhao and Running (2010) }\end{array}$} \\
\hline & & T-Cor & & $0.87^{\mathrm{b}}$ & \\
\hline & & S-Cor & & $0.88^{\mathrm{b}}$ & \\
\hline \multirow[t]{3}{*}{ NPP } & 2000-2004 & Avg & 54 & 54 & \\
\hline & & T-Cor & & $0.75^{\mathrm{b}}$ & \\
\hline & & S-Cor & & $0.81^{\mathrm{b}}$ & \\
\hline
\end{tabular}

${ }^{\mathrm{a}}$ Burned area fraction rather than burned area is used. ${ }^{\mathrm{b}}$ Pearson correlation passed the student's $t$ test at the $\alpha=0.05$ significance level. ${ }^{\mathrm{c}}$ Pearson correlation passed the student's $t$ test at the $\alpha=0.1$ significance level.

based estimates might have a large uncertainty in temporal pattern because a small number of flux towers were available in tropical ecosystems and the tropical ecosystems largely drove the interannual variability in the carbon cycle (Denman et al., 2007). Regarding the spatial pattern, the CLM4.5 simulation and the two benchmarks show the highest GPP in tropical forests, followed by temperate and boreal forests; and the lowest value in high-latitude regions with short growing seasons and deserts (Fig. S5). The spatial correlation is 0.90 between the CLM4.5 simulation and the FLUXNETbased estimates, and 0.88 between CLM4.5 and the satellitebased estimates, indicating that the CLM4.5 simulation and the two benchmarks are in good agreement in describing the large-scale GPP distribution.

With respect to NPP, the 2000-2004 average of global total is $54 \mathrm{PgC} \mathrm{yr}^{-1}$ for CLM4.5, the same with the satellitebased estimates (Zhao et al., 2005; Zhao and Running, 2010). CLM4.5 captures the decline of NPP from 2000 to 2002 and the increase from 2002 to 2004. The temporal correlation between CLM4.5 and the satellite-based estimates is
0.75 , significant at the 0.05 level. Spatial patterns of NPP from CLM4.5 and the satellite-based estimates are significantly correlated (global spatial correlation: 0.81) and similar to their spatial patterns of GPP (Fig. S6).

\subsection{Simulated burned area in the 20th century}

Information about historical burned areas during the 20th century provides some background to understanding the impact of fire on the global carbon budget in Sect. 3. The average global burned area of CLM4.5 over 1900-1999 is

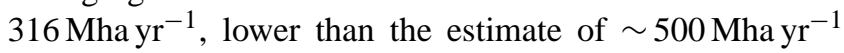
by Mouillot and Field (2005). However, Mouillot and Field (2005) may overestimate the 20th century average of global burned areas, because it estimated areas burned at the end of the 20th century to be $\sim 1.5$ times bigger than GFED3 (Giglio et al., 2010) and GBA2000 (Grégoire et al., 2003), and its contemporary burned area was used to scale its historical reconstruction.

The long-term trend of the simulated global burned area presents a shift in $\sim 1970$. It shows a downward trend of 

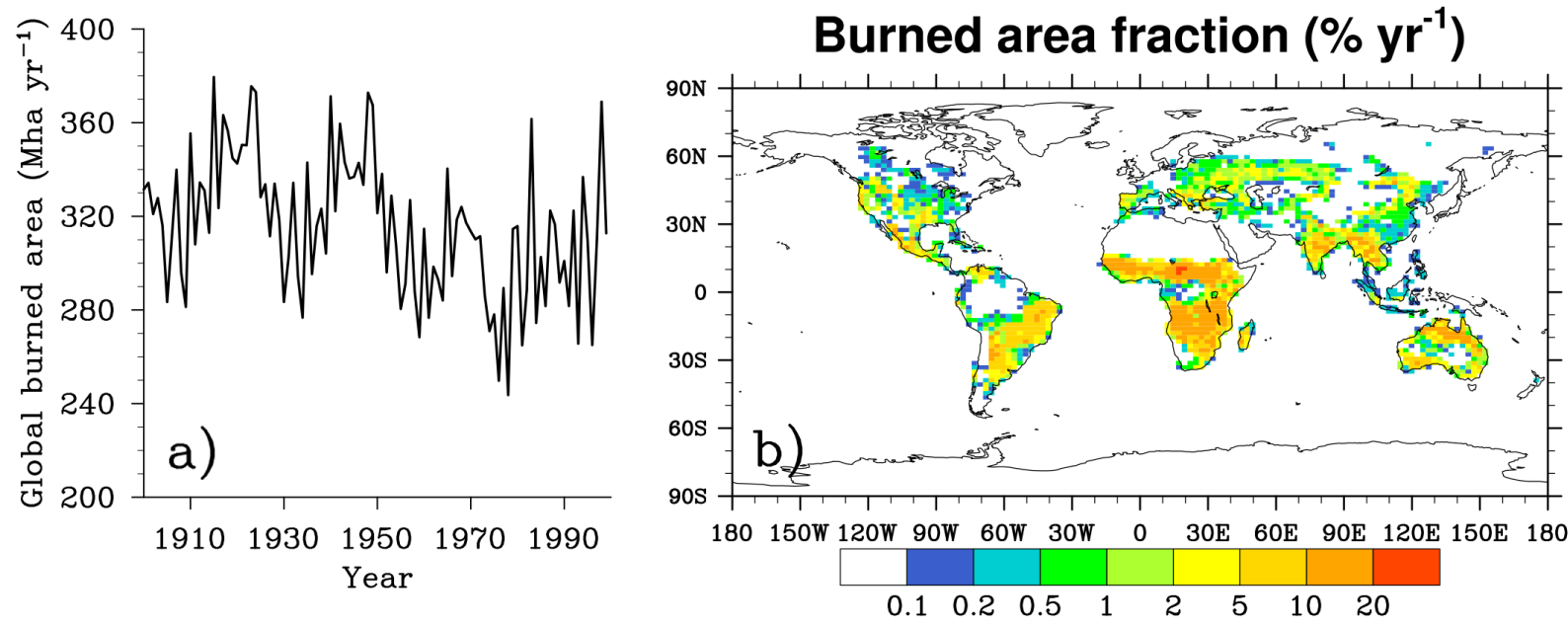

Fig. 1. (a) 1900-1999 historical variability of global total of annual burned areas and (b) global spatial distribution of 1900-1999 average annual burned area fractions.

$-0.33 \mathrm{Mha} \mathrm{yr}^{-1}$ from 1900 to 1971 , followed by an upward trend of $1.37 \mathrm{Mha} \mathrm{yr}^{-1}$ after 1972 (Fig. 1a). Both trends are significant at the 0.05 level according to the Mann-Kendall trend test. The simulated long-term trend is similar to that in the reconstructed burned area of Mouillot and Field (2005). The long-term trend in Mouillot and Field (2005) was based on published data, data on land-use practices, qualitative reports, as well as local studies such as tree ring analysis. Note that the 25-yr cycles shown in the simulated global burned area before $\sim 1970$ are due to the cycling of the 1948-1972 atmospheric forcing.

For the 20th century, CLM4.5 simulates a high burned area fraction in tropical savannas, a moderate fraction in northern Eurasia and the Rocky Mountains, and a low fraction in arid regions due to low fuel availability and in humid forests due to low fuel combustibility (Fig. 1b). The global spatial pattern of burned areas in CLM4.5 is similar to that in Mouillot and Field (2005).

\section{Impact of fire on the net carbon balance of global terrestrial ecosystems (NEE)}

\subsection{Total effect of fire}

The 1900-1999 average of global NEE is $-0.1 \mathrm{Pg} \mathrm{C} \mathrm{yr}^{-1}$ for the fire-on simulation and $-1.1 \mathrm{Pg} \mathrm{C} \mathrm{yr}^{-1}$ for the fire-off simulation, respectively (Table 2). Their difference (fire-on minus fire-off) is $1.0 \mathrm{Pg} \mathrm{C} \mathrm{yr}^{-1}$, which can pass the student's $t$ test at the 0.05 significance level, indicating that fire significantly decreases the net land carbon sink averaged across the 20th century. The simulated fire effect for 1960-1999 (0.8 Pg

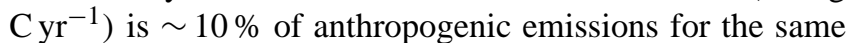
period (Le Queré et al., 2013).

Figure 2 shows the time series of annual NEE in fireon and fire-off simulations and their differences. As shown in Fig. 2, annual NEE in the fire-on simulation fluctuates around zero prior to $\sim 1970$, while often showing a negative value (i.e., land is a carbon sink) during the following three decades. The temporal pattern of NEE during the 20th century in CLM4.5 is similar to that simulated by the ORCHIDEE global process-based vegetation model with the sub-model of vegetation dynamics turned off (Piao et al., 2009). Fire increases annual NEE for the whole period. Long-term trend in fire effect has a shift around 1970. The fire effect declines before 1971 with a linear trend of $-8 \mathrm{Tg}$ $\mathrm{C} \mathrm{yr}^{-1}$ and increases after 1972 with a linear trend of $18 \mathrm{Tg}$ $\mathrm{C} \mathrm{yr}^{-1}\left(\mathrm{Tg}=10^{12} \mathrm{~g}\right)$. Both trends are significant at the 0.05 level.

As shown in Fig. 3, the difference in the average of annual NEE is generally positive in post-fire regions. The difference is significant over tropical savannas mainly due to high burned area fraction and some North American and East Asian forests mainly due to high carbon storage.

NEE is the change in ecosystem carbon storage during a period. Fire increases the 20th century average of annual NEE (i.e., decreases the net carbon gain of land) (Table 2 and Fig. 3), indicating that the 100-yr average of ecosystem carbon storage in the fire-on simulation is smaller than that in the fire-off simulation. This can be supported by the site-level field observations from San Jose et al. (1998), Tilman et al. (2000), Shackleton and Scholes (2000), Wang et al. (2001), and Irvine et al. (2007), which reported that ecosystem carbon pools in burned stands were smaller than those in unburned stands on various timescales (from less than to many times normal fire return intervals, from several years to more than one hundred years) and for various ecosystems (savanna and forests). Moreover, our results are consistent with Bond-Lamberty et al. (2007), who showed that fire decreased net biomass productivity (i.e., increased NEE) for 1948-2005 in a central Canadian boreal forest 
Table 2. The 20th century average of global annual NEE, fire carbon emissions, net ecosystem production (NEP), NPP, heterotrophic respiration (Rh), GPP, autotrophic respiration $(\mathrm{Ra})$, and carbon loss due to land use and wood harvest $\left(C_{\mathrm{lh}}\right)$, and $-\mathrm{NEP}+C_{\mathrm{lh}}$ in fire-on and fire-off simulations and their difference (fire-on minus fire-off) in the two simulations. Fire direct and indirect effects on the mean of the terrestrial carbon balance are quantified by the difference in fire carbon emissions and $-\mathrm{NEP}+C_{\mathrm{lh}}$, respectively. Units are $\mathrm{Pg}$ $\mathrm{C} \mathrm{yr}^{-1}$. In CLM4.5, NEE $=-\mathrm{NEP}+C_{\mathrm{lh}}+$ fire carbon emissions, where NEP $=$ NPP-Rh and NPP $=$ GPP-Ra.

\begin{tabular}{lrrr}
\hline Variables & $\begin{array}{r}\text { Fire-on } \\
\text { minus fire-off }\end{array}$ & Fire-on & Fire-off \\
\hline NEE & $1.0^{*}$ & -0.1 & -1.1 \\
\hline Fire carbon emissions & $1.9^{*}$ & 1.9 & 0.0 \\
\hline$-\mathbf{N E P}+\boldsymbol{C}_{\mathbf{l h}}$ & $-0.9^{*}$ & -2.0 & -1.1 \\
\hline $\mathbf{N E P}$ & $0.8^{*}$ & 3.0 & 2.3 \\
$\mathrm{NPP}$ & $-1.9^{*}$ & 49.6 & 51.6 \\
$\mathrm{Rh}$ & $-2.7^{*}$ & 46.6 & 49.3 \\
$\mathrm{GPP}$ & $-5.0^{*}$ & 118.9 & 123.9 \\
$\mathrm{Ra}$ & $-3.1^{*}$ & 69.3 & 72.4 \\
\hline $\boldsymbol{C}_{\mathbf{l h}}$ & -0.1 & 1.0 & 1.1 \\
\hline
\end{tabular}

* Difference in the means between fire-on and fire-off simulations passed the student's $t$ test at $\alpha=0.05$ significance level.

based on the Biome-BGC process-based ecosystem model. In addition, as shown in Fig. 2, the difference in NEE between the fire-on and fire-off simulations (fire-on minus fireoff) is always positive, meaning that ecosystem carbon storage in the fire-off simulation increases with fire-exclusion time compared with the fire-on simulation, in agreement with the field observations of San Jose et al. (1998) that ecosystem carbon pools increased with years after savanna protection.

\subsection{Direct and indirect effects of fire}

In this section, in order to investigate the mechanisms concerning the effect of fire on NEE, fire effect is further separated into two parts: the direct effect in Sect. 3.2.1 and the indirect effect in Sect. 3.2.2.

\subsubsection{Direct effect of fire}

The 20th century average of fire carbon emissions (i.e., the fire direct effect) is $1.9 \mathrm{Pg} \mathrm{C} \mathrm{yr}^{-1}$ (Table 2). Our estimate is higher than Ward et al. (2012) $\left(\sim 1.7 \mathrm{Pg} \mathrm{Cyr}^{-1}\right)$, but lower than Mouillot et al. (2006) $\left(\sim 2.5 \mathrm{Pg} \mathrm{Cyr}^{-1}\right)$. Ward et al. (2012) pointed out that they underestimated the global fire carbon emissions mainly due to the simulation bias in Northern Hemisphere tropical fires. Mouillot et al. (2006) estimated $\sim 3.0 \mathrm{Pg} \mathrm{C} \mathrm{yr}^{-1}$ of fire carbon emissions at the end of the 20th century, which was much higher than GFED3 $\left(\sim 2.0 \mathrm{Pg} \mathrm{Cyr}^{-1}\right)$.

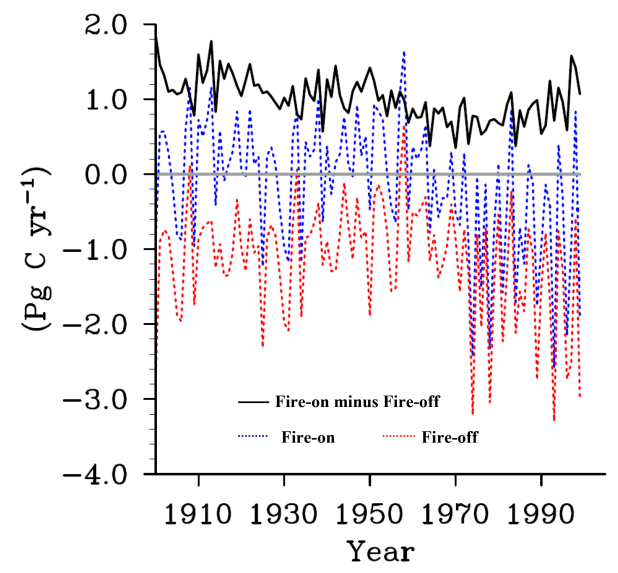

Fig. 2. Global totals of annual NEE in fire-on (blue) and fire-off (red) simulations for 1900-1999, and their differences (black). A negative value of NEE for fire-on and fire-off simulations indicates a land uptake of carbon.

Global fire carbon emissions do not show an obvious longterm trend before $\sim 1970$, but do present a significant (at the

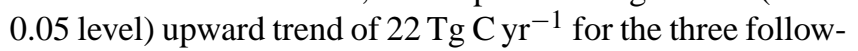
ing decades (Fig. 4a). The different trend between fire carbon emissions and the burned area shown in Fig. 1a is mainly because fuel load in the majority of regions likely to burn (defined here as grid cells with simulated 1900-1999 average burned area factions no lower than $0.01 \% \mathrm{yr}^{-1}$ ) and tropical deforestation fires increase with time during the 20th century. The weak long-term trend in fire carbon emissions before $\sim 1970$ is similar to earlier estimates from GICC (Mieville et al., 2010), Kloster et al. (2010), and Ward et al. (2012), and falls into the likely range of long-term trends from Mouillot et al. (2006). It is also in the range of trends shown in earlier reconstructions based on charcoal records (Marlon et al., 2008, 2013), CO records in Antarctic ice core (Wang et al., 2010; Prentice, 2010), $\mathrm{CH}_{4}$ records in Antarctic ice core (Ferretti et al., 2005), and a global numerical model (van der Werf et al., 2013). The reconstructions based on the charcoal records and the $\mathrm{CO}$ records show a clear downward trend, contrary to that shown in the last two reconstructions. The significant upward trend of fire carbon emissions in CLM4.5 since $~ 1970$ is consistent with Mouillot et al. (2006), RETRO (Schultz et al., 2008), GICC (Mieville et al., 2010), and Kloster et al. (2010). The 25-yr cycles shown in the simulated global fire carbon emissions before $\sim 1970$ are due to the cycling of the 1948-1972 atmospheric forcing used in the present study.

CLM4.5 simulates the high carbon emissions in tropical savannas in Africa, South America, and South Asia, the moderate carbon emissions in Canada and around $50^{\circ} \mathrm{N}$ in Eurasia, and the low emissions in desert, frozen soil regions, and the core of tropical closed forests (Fig. 4b). The spatial pattern is similar to that of GICC (Mieville et al., 2010). 


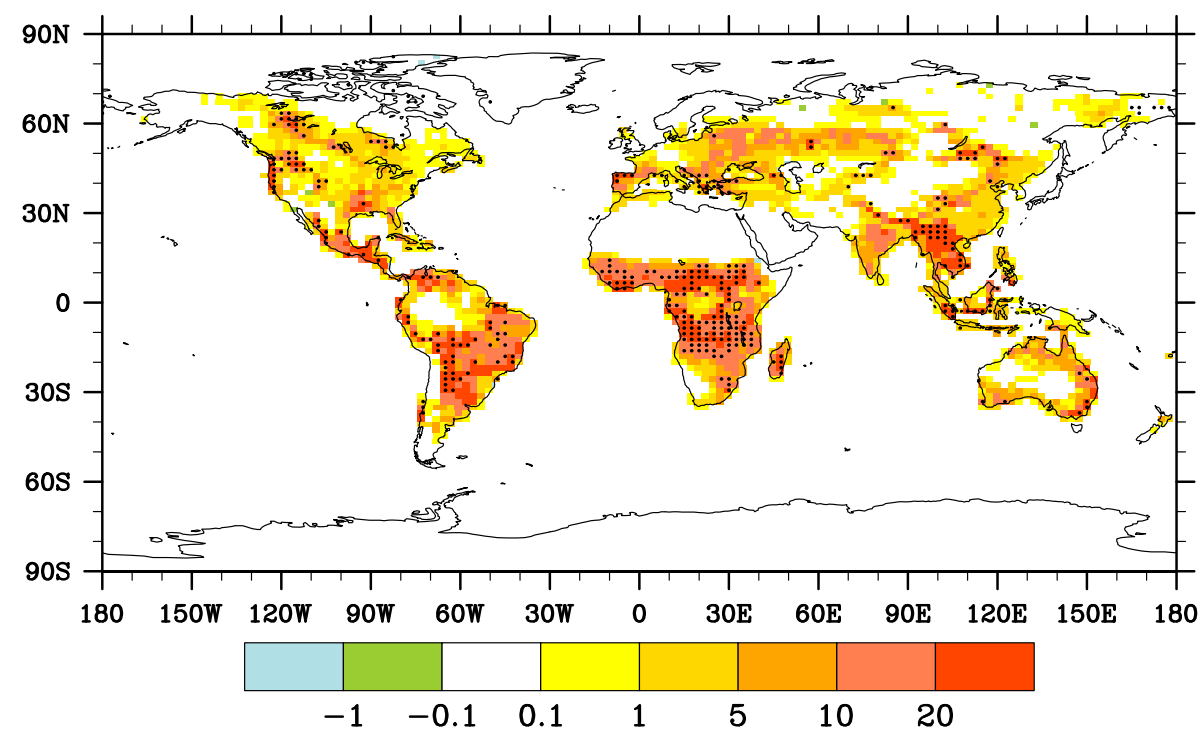

Fig. 3. Difference (fire-on minus fire-off) in the 1990-1999 average NEE from fire-on and fire-off simulations. Difference passed the student's $t$ test at the $\alpha=0.05$ significance level is stippled. Unit is $\mathrm{g} \mathrm{C} \mathrm{m}^{-2} \mathrm{yr}^{-1}$.
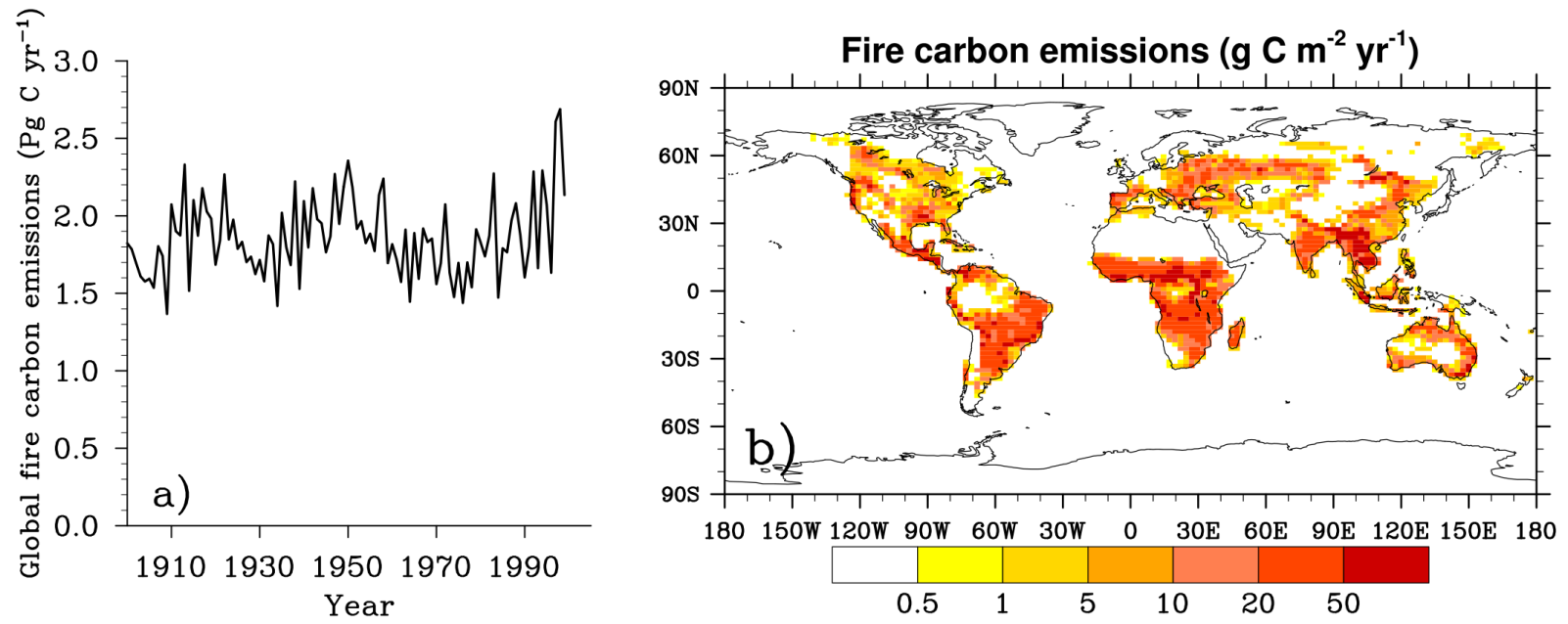

Fig. 4. Same as Fig. 1, but for fire carbon emissions.

\subsubsection{Indirect effect of fire}

As shown in Table 2, the indirect effect of fire (i.e., the difference in $-\mathrm{NEP}+C_{\mathrm{lh}}$ ) increases the land carbon sink by $0.9 \mathrm{Pg}$ $\mathrm{C} \mathrm{yr}^{-1}$ (fire-on: $-2.0 \mathrm{Pg} \mathrm{C} \mathrm{yr}^{-1}$; fire-off: $-1.1 \mathrm{Pg} \mathrm{C} \mathrm{yr}^{-1}$ ), which offsets $42 \%$ of fire carbon emissions. The fire indirect effect is primarily driven by the influence of fire on NEP. Fire increases NEP by $0.8 \mathrm{Pg} \mathrm{C} \mathrm{yr}^{-1}$ (fire-on: $3.0 \mathrm{Pg} \mathrm{C} \mathrm{yr}^{-1}$; fireoff: $2.3 \mathrm{Pg} \mathrm{C} \mathrm{yr}^{-1}$ ) and decreases $C_{\mathrm{lh}}$ by $0.1 \mathrm{Pg} \mathrm{C} \mathrm{yr}^{-1}$ (fireon: $1.0 \mathrm{Pg} \mathrm{C} \mathrm{yr}^{-1}$; fire-off: $1.1 \mathrm{Pg} \mathrm{C} \mathrm{yr}^{-1}$ ). The differences between fire-on and fire-off simulations for $-\mathrm{NEP}+C_{\mathrm{lh}}$ and NEP are significant at the 0.05 level.

As shown in Fig. 5, the differences in $-\mathrm{NEP}+C_{\mathrm{lh}}$, NEP, and $C_{\mathrm{lh}}$ increase with time during the 20th century. The fire indirect effect has an upward trend of $7 \mathrm{Tg} \mathrm{C} \mathrm{yr}^{-1}$. Linear trends of the difference between fire-on and fire-off simulations are 5 and $-2 \mathrm{Tg} \mathrm{C} \mathrm{yr}^{-1}$ for NEP and $C_{\mathrm{lh}}$, respectively. All of the three trends are significant at the 0.05 level. Unlike the burned area (Fig. 1a) and fire carbon emissions (Fig. 4a), the indirect effect of fire and the impact of fire on NEP and $C_{\text {lh }}$ do not show a shift in their long-term trends, implying that they mainly correspond to the growing difference in fire history between the fire-on and fire-off simulations.

As shown in Fig. 6, fire generally increases the average NEP in post-fire regions. Its spatial pattern is similar to that of fire carbon emissions shown in Fig. 4b, but with smaller magnitude. Moreover, fire decreases $C_{\mathrm{lh}}$ in post-fire regions where the land cover changed. Both the effects of fire on NEP and $C_{\mathrm{lh}}$ generally contribute to the land carbon sink, so their 

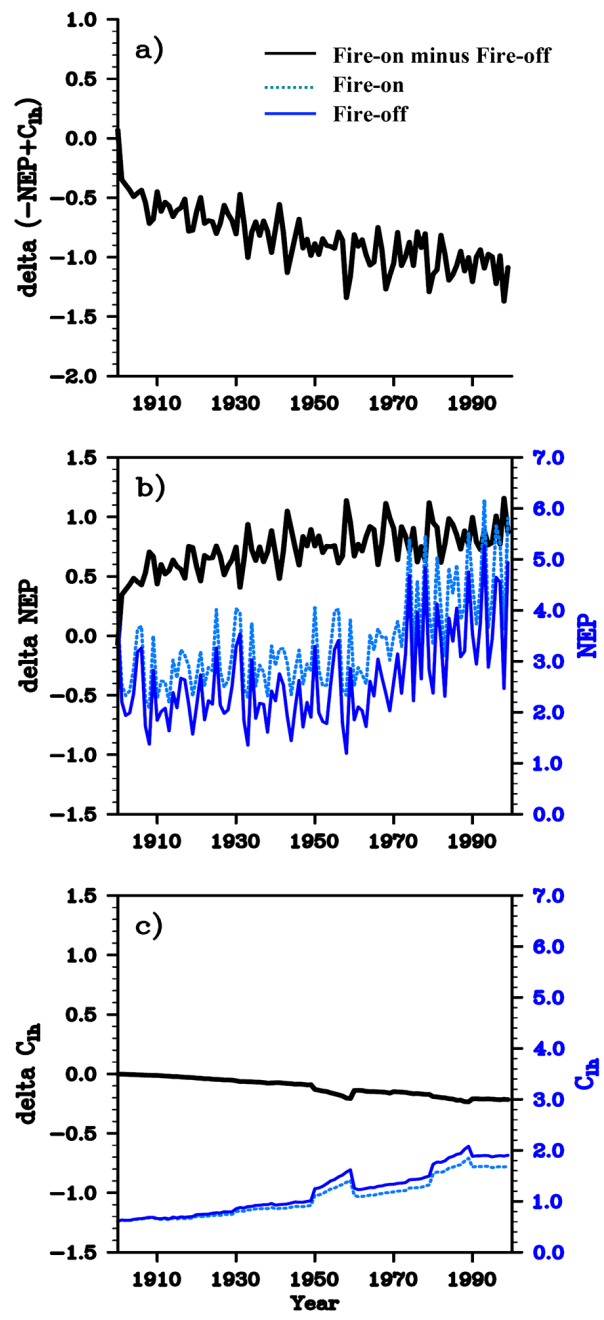

Fig. 5. (a) Fire indirect impact on NEE; (b) NEP and (c) $C_{\mathrm{lh}}$ in fireon and fire-off simulations and their differences. Unit is $\mathrm{Pg} \mathrm{C} \mathrm{yr}^{-1}$.

total effects (i.e., the fire indirect effect) generally increases the land carbon sink in post-fire regions.

That NEP is higher in the fire-on simulation than that in the fire-off simulation can be supported by earlier studies. Based on forest chronosequences, Law et al. (2003), Campbell et al. (2004), Bond-Lamberty et al. (2004), Goulden et al. (2006), Amiro et al. (2010), and Goulden et al. (2011) reported that NEP after a fire was higher than its pre-fire value except for a very short period at the beginning of postfire succession. Their findings were also reproduced by earlier modeling studies (Thornton et al., 2002; Hicke et al., 2003; Bond-Lamberty et al., 2007; Yi et al., 2013; Yue et al., 2013) and are consistent with the ecosystem succession theory (Odum, 1969). In addition, as noted by Houghton et al. $(1999,2000)$ and Ward et al. (2012), fire maintained a lower ecosystem carbon storage and would decrease land carbon loss if land use occurred. This is also the case in our simulations, in which we find a lower land-use carbon
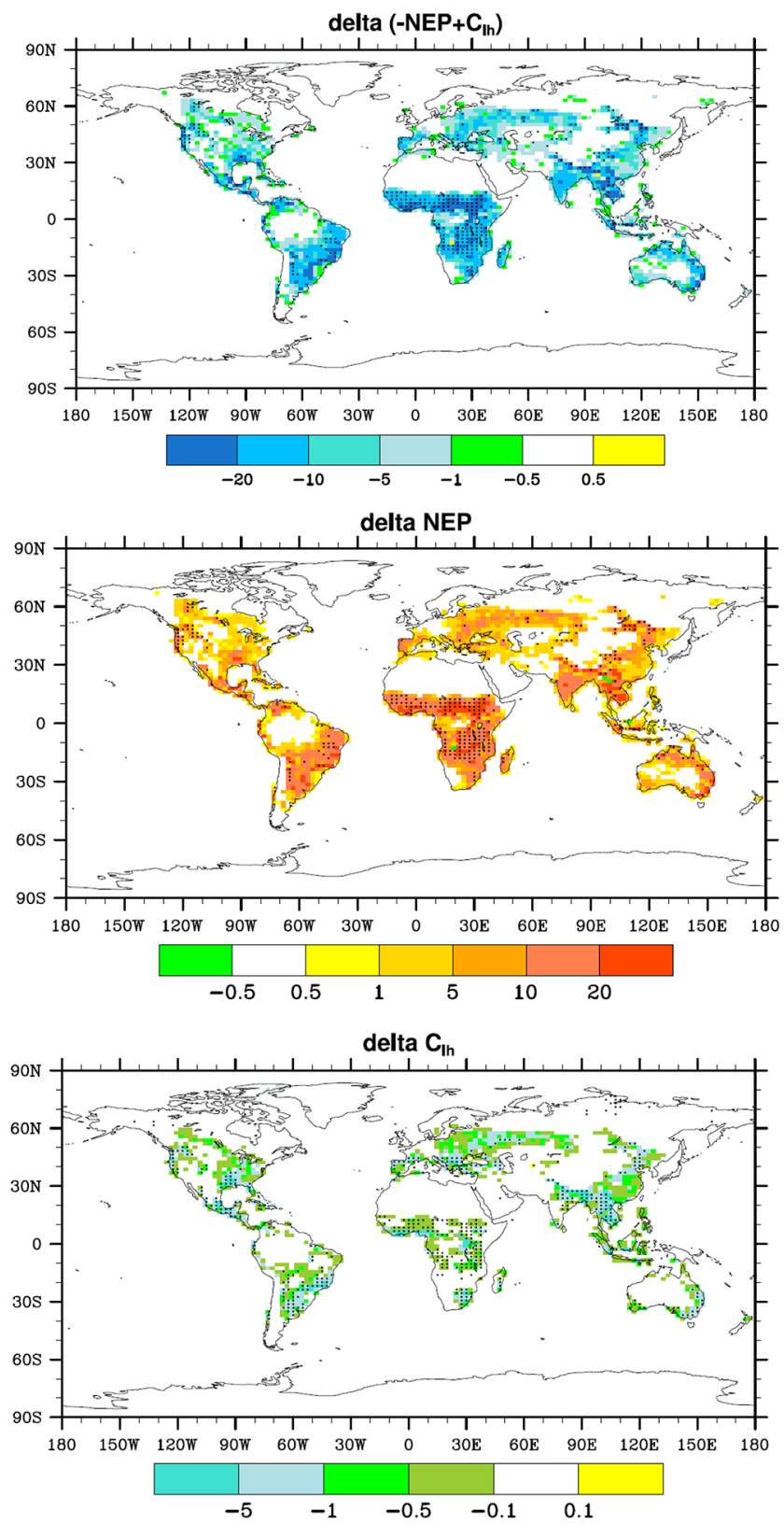

Fig. 6. Difference (fire-on minus fire-off) in the average of annual $-\mathrm{NEP}+C_{\mathrm{lh}}, \mathrm{NEP}$, and $C_{\mathrm{lh}}$ for 1900-1999. The difference for $-\mathrm{NEP}+C_{\mathrm{lh}}$ represents the fire indirect effect. Difference in average with the student's $t$ test at $\alpha=0.05$ significance level is stippled. Unit is $\mathrm{g} \mathrm{C} \mathrm{m}^{-2} \mathrm{yr}^{-1}$.

loss in the fire-on simulation than that in the fire-off simulation. Fire-induced decrease in land-use carbon loss averages $0.1 \mathrm{Pg} \mathrm{C} \mathrm{yr}^{-1}$ across the 20th century in our present study, which is smaller than the estimate of $\sim 0.2 \mathrm{Pg} \mathrm{C} \mathrm{yr}^{-1}$ in Ward et al. (2012) because the impact of fire before the 20th century on carbon storage was considered in Ward et al. (2012).

To understand the effect of fire on NEP in CLM4.5, we also investigate the impact of fire on its components: GPP, 

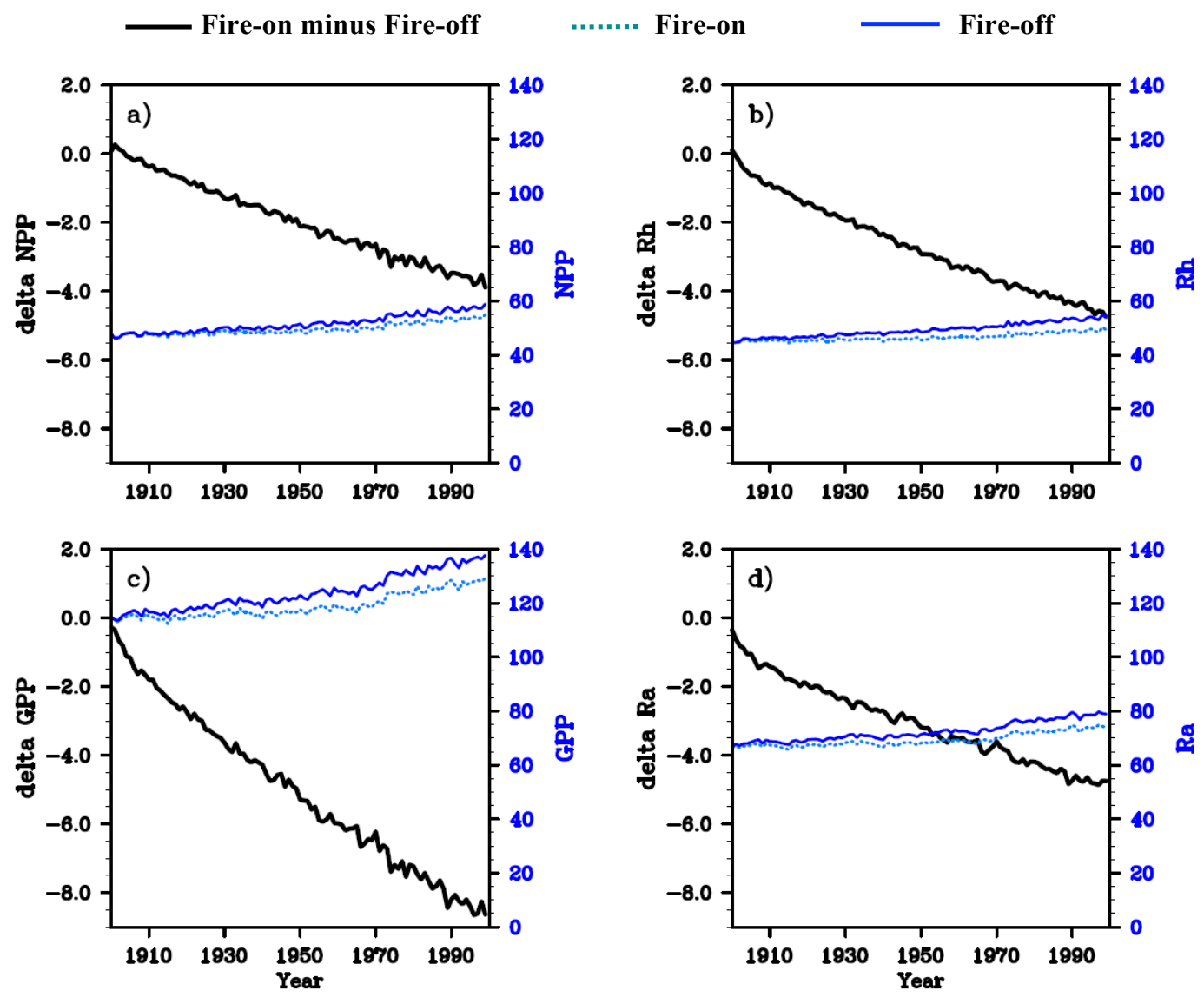

Fig. 7. Same as Fig. $5 b$ and c, but for (a) NPP, (b) Rh, (c) GPP, and (d) Ra.

Ra, NPP, and Rh. As shown in Table 2, fire decreases the 20th century average of global NPP, Rh, GPP and Ra by 1.9, 2.7, 5.0, and 3.1 $\mathrm{Pg} \mathrm{Cyr}^{-1}$, which are significant at the 0.05 level. The difference in these fluxes between the fire-on and fire-off simulations increases with time, with linear trends

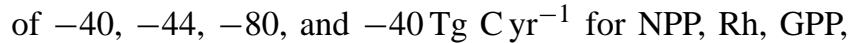
and Ra, respectively (Fig. 7). With respect to spatial patterns, fire generally decreases all four fluxes in post-fire regions (not shown). Their spatial patterns are similar to those of the impact of fire on NEP (Fig. 6), but with opposite signs. In CLM4.5, fire decreases GPP mainly because fire decreases the grid-cell photosynthesizing leaf area. Less carbon supply due to reduced GPP and less carbon demand due to firerelated decrease in live vegetation tissue contribute to the lower Ra in the fire-on simulation. The lower NPP in the fireon simulation is because NPP is mainly determined by GPP (annual GPP is much greater than annual Ra). The decrease in $\mathrm{Rh}$ in post-fire regions is mainly because fire decreases the $\mathrm{C}$ availability for decomposition by reducing carbon input to the terrestrial ecosystems and by burning of litter and CWD. Fire increases NEP because the decrease in NPP due to fire is smaller than the decrease in Rh. This can be supported by earlier studies based on observations (Law et al. 2003; Amiro et al., 2010; Goulden et al., 2011) and modeling (Yue et al., 2013), which showed that post-fire recovery of GPP, Ra, and NPP was generally faster than that of Rh.

\section{Discussion and conclusions}

In this study, we provide the first quantitative assessment regarding the impact of fire on the net carbon balance of global terrestrial ecosystems during the 20th century. The CLM4.5 global land surface model is used as the model platform, and overall it reproduces the observed global total, temporal variability, and large-scale spatial pattern of present-day fire and carbon fluxes. The difference between the 20th century fire-on and fire-off simulations is used to quantify the fire effect. Moreover, the roles of fire's direct (i.e., fire carbon emissions) and indirect (i.e., fire influences the NEP and land-use carbon emissions through changing terrestrial characteristics) effects on the net carbon balance are investigated. Our main findings can be summarized as follows:

- Global total averaged across the 20th century: fire significantly decreases the net carbon gain of global terrestrial ecosystems by $1.0 \mathrm{Pg} \mathrm{Cyr}^{-1}$, which is the re- 
sult of $42 \%$ of fire carbon emissions $\left(1.9 \mathrm{Pg} \mathrm{C} \mathrm{yr}^{-1}\right)$ offset by the fire indirect effect $\left(-0.9 \mathrm{Pg} \mathrm{C} \mathrm{yr}^{-1}\right)$.

- Temporal variability: the difference in annual global NEE between the fire-on and fire-off simulations (fireon minus fire-off) is always positive during the 20th century, because the global fire carbon emissions are always higher than the fire indirect effect. The effect of fire on NEE significantly declines prior to 1971 (trend:

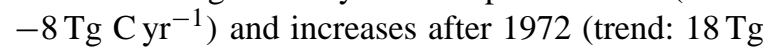

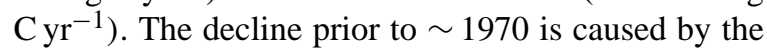
increase in the fire indirect effect. The increase since $\sim 1970$ is due to the significant increase in fire carbon emissions, although $32 \%$ of the upward trend in the fire carbon emissions is offset by the fire indirect effect.

- Spatial pattern: fire generally decreases the carbon gain of terrestrial ecosystems in post-fire regions because spatial patterns of the fire direct and indirect effects are similar and the fire direct effect (decreasing the carbon gain of land) is stronger than the indirect effect (increasing the carbon gain of land). The total and indirect effects are significant over savannas in Africa and South America mainly due to the high burned area fraction and some North American and East Asian forests mainly due to the high terrestrial carbon storage, where the direct effect is also strong.

Several sources of uncertainty in our estimates are worth noting. First, our simulations before 1948 are forced by cycling 25-yr (1948-1972) atmosphere observations from Qian et al. (2004). The atmosphere observations from Qian et al. (2004) cover 1948-2004 in total. Our simulations before 1948 are therefore only driven by external forcing factors: population density, atmospheric $\mathrm{CO}_{2}$ concentration, nitrogen and aerosol deposition, land use and land cover change, and wood harvest. This may affect our trend analysis of fire effects.

Second, the vegetation distribution in our CLM4.5 simulations is prescribed, although other ecosystem characteristics (e.g., LAI, biomass, and carbon fluxes) are dynamically simulated. Therefore, the effect of fire on net carbon balance through changing vegetation distribution is not accounted for in our present estimates, similar to most earlier site-level and regional modeling studies (Thornton et al., 2002; Law et al., 2003; Hicke et al., 2003; Ward et al., 2012; Yue et al., 2013). Based on a dynamical global vegetation model SDGVM, Bond et al. (2005) showed that global closed forest cover (80-100\% tree cover) was $56.4 \%$ of vegetated grid cells for the 20th century fire-off simulation, compared with the $26.9 \%$ for control simulation. Though Bond et al. (2005) may substantially overestimate the importance of fire in the adjustment of vegetation distribution due to the modeling bias in grass-tree competition (Scheiter and Higgens, 2009), earlier studies (San Jose et al., 1998; Staver et al., 2011;
Murphy and Bowman, 2012) reported that fire could limit tree cover in some regions. In the present study, the prescribed changing land use/land cover used in both simulations is partly the result of historical fires, so that the effect of fires is not totally excluded in the fire-off simulation. If the impact of fire on vegetation distribution is considered, the carbon sink may become bigger over some transition zones between woody and herbaceous plants in the fire-off simulation, thereby increasing the estimates of fire effect on the net carbon balance.

Third, CLM4.5 is not coupled with an atmosphere model in the present study, so our estimates do not consider the real-time feedback of fire-induced change in climate, trace gases, and aerosols. Our fire-off simulation shows higher LAI and land carbon sink than the fire-on simulation. If CLM4.5 is coupled with an atmosphere model, the difference between fire-on and fire-off simulations will probably be magnified due to the positive vegetation-climate feedbacks reported by Charney (1975), Dickinson and Kennedy (1992), Levis et al. (1999, 2004a), Brovkin et al. (2003), Bonan et al. (2008a), and Delire et al. (2011). The positive vegetationclimate feedbacks may also enlarge the fire effect on NEE by changing the terrestrial water and heat states. In the present study, the impact of fire on terrestrial water and heat states is weak and may be suppressed because the same atmospheric forcing is used for the simulations with and without fire. Moreover, earlier studies reported that fire emissions would increase atmospheric $\mathrm{CO}_{2}$ concentration (Jacobson, 2004; Ward et al., 2012; D. S. Ward, personal communication, 2013). If a lower atmospheric $\mathrm{CO}_{2}$ concentration is considered in fire-off simulation, terrestrial carbon sink in fireoff simulation and the effect of fire on NEE will be decreased according to earlier carbon-concentration studies (Bonan and Levis, 2010; Arora et al., 2013). In addition, the net cooling influence of fire trace gas and aerosol emissions reported by Randerson et al. (2006) and Ward et al. (2012) may reduce the fire effects on NEE, given that cooling can increase terrestrial carbon sink by reducing ecosystem respiration (Bonan, 2008b).

The last two limitations in our estimates could be solved by using a dynamic global vegetation model (DGVM) and coupling it with an atmosphere model. However, explaining these simulation results will be challenging because biases in DGVMs and atmosphere models will be inevitably introduced in and may be enlarged by positive vegetation-climate feedbacks (Bonan and Levis, 2006). In particular, current DGVMs have difficulty in reproducing the transition zones between woody and herbaceous plants, which are the key regions for the impact of fire on vegetation distribution, though they are good at capturing the central regions of major vegetation categories (Sitch et al. 2003; Levis et al. 2004b; Bond et al., 2005; Castillo et al., 2012; Zeng et al., 2014). Also, existing atmosphere models still have large biases and uncertainties in simulating precipitation over land (Dai et al., 2006; Hegerl, et al., 2007; Joetzjer et al., 2013; Kumar et al., 
2013). Precipitation over land is an important variable for the simulation of vegetation, carbon, and fire. In addition, so far, DGVMs have not been able to co-work with land-use data yet, and many earlier studies already justified the importance of land use in the global carbon cycle (Houghton et al., 1999; Denman et al., 2007; Lawrence et al., 2012). If a DGVM is used as the model platform, there will be bias in the simulation of net carbon balance because land use will not be taken into account.

\section{Supplementary material related to this article is available online at http://www.biogeosciences.net/11/ 1345/2014/bg-11-1345-2014-supplement.pdf.}

Acknowledgements. This study is co-supported by the Strategic Priority Research Program of the Chinese Academy of Sciences under grant no. XDA05110201, the State Key Project for Basic Research Program of China (973) under grant no. 2010CB951801, and the National Natural Science Foundation under grant no. 41005052. We are grateful to D. S. Ward from Cornell University, X.-D. Zeng and Z.-D. Lin from the Institute of Atmospheric Physics, Chinese Academy of Sciences, D. M. J. S. Bowman from the University of Tasmania, C. D. Koven from the Lawrence Berkeley National Lab, and K. Trenberth from the National Center for Atmospheric Research (NCAR) for helpful discussions. We thank L. Giglio from the NASA Goddard Space Flight, G. R. van der Werf from VU University, M. Jung and C. Röedenbeck from the Max Planck Institute for Biogeochemistry, M.-S. Zhao from the University of Montana, and F. Chevallier from the Laboratory of Sciences of the Climate and Environment (LSCE) for making their data available. We also thank the two anonymous reviewers for their valuable comments and suggestions, Editor S. Liu for handling this paper, and J. Xiao, S. Liu and P. Story for organizing the special issue. Computing resources were provided by the NCAR, which is sponsored by the National Science Foundation. B. Bond-Lamberty is funded by the DOE Office of Science Integrated Assessment Research Program and Earth System Modeling Program, as part of the integrated Earth System Modeling Project.

\section{References}

Amiro, B. D., et al.: Ecosystem carbon dioxide fluxes after disturbance in forests of North America, J. Geophys. Res., 115, G00K02, doi:10.1029/2010JG001390, 2010.

Andreae, M. O. and Merlet, P.: Emission of trace gases and aerosols from biomass burning, Global Biogeochem. Cy., 15, 955-966, 2001.

Arino, O. and Rosaz, J. M.: 1997 and 1998 world ATSR fire atlas using ERS-2 ATSR-2 data, in: 15 Proceedings of the Joint Fire Science Conference and Workshop, edited by: Neuenschwander, L. F., Ryan, K. C., and Gollberg, G. E., vol. 1, University of Idaho and the International Association of Wildland Fire, Boise, Idaho, 177-182, 1999.

Arora, V. K. and Boer, G. J.: Fire as an interactive component of dynamic vegetation models, J. Geophys. Res., 110, G02008, doi:10.1029/2005JG000042, 2005.
Arora, V., Boer, G., Friedlingstein, P., Eby, M., Jones, C., Christian, J., Bonan, G., Bopp, L., Brovkin, V., Cadule, P., Hajima, T., Ilyina, T., Lindsay, K., Tjiputra, J., and Wu, T.: Carbon concentration and carbon-climate feedbacks in CMIP5 Earth system models, J. Climate, 26, 5289-5314, 2013.

Bonan, G. B.: Forests and climate change: Forcings, feedbacks, and the climate benefits of forests, Science, 320, 1444-1449, 2008a.

Bonan, G. B.: Ecological Climatology: Concepts and Applications, 2nd edition, Cambridge University Press, Cambridge, 550 pp., 2008 b.

Bonan, G. B. and Levis, S.: Quantifying carbon-nitrogen feedbacks in the Community Land Model(CLM4), Geophys. Res. Lett., 37, L07401, doi:10.1029/2010GL042430, 2010.

Bonan, G. B., Lawrence, P. J., Oleson, K. W., Levis, S., Jung, M., Reichstein, M., Lawrence, D. M., and Swenson, S. C.: Improving canopy processes in the Community Land Model (CLM4) using global flux fields empirically inferred from FLUXNET data, J. Geophys. Res., 116, G02014, doi:10.1029/2010JG001593, 2011.

Bond, W. J., Woodward, F., and Midgley, G. F.: The global distribution of ecosystems in a world without fire, New Phytol., 165, 525-538, 2005.

Bond-Lamberty, B., Wang, C., and Gower, S. T.: Net primary production and net ecosystem production of a boreal black spruce wildfire chronosequence, Glob. Change Biol., 10, 473487, 2004.

Bond-Lamberty, B., Peckham, S. D., Ahl, D. E., and Gower, S. T.: Fire as the dominant driver of central Canadian boreal forest carbon balance, Nature, 450, 89-92, 2007.

Bowman, D. M. J. S., et al.: Fire in the Earth System, Science, 324, 480-484, 2009.

Brovkin, V., Levis, S., Loutre, M. F., Claussen, M., Crucifix, M., Ganopolski, A., Kubatzki, C., and Petoukhov, V.: Stability analysis of the climate-vegetation system in the northern high latitudes, Clim. Change, 57, 119-138, 2003.

Campbell, J. L., Sun, O., and Law, B. E.: Disturbance and net ecosystem production across three climatically distinct forest landscapes, Global Biogeochem. Cy., 18, GB4017, doi:10.1029/2004GB002236, 2004.

Castillo, C. K. G., Levis, S., and Thornton, P. E.: Evaluation of the New CNDV Option of the Community Land Model: Effects of Dynamic Vegetation and Interactive Nitrogen on CLM4 Means and Variability, J. Climate, 25, 3702-3714, 2012.

Charney, J.: Dynamics of deserts and droughts in the Sahel, Q. J. Roy. Meteor. Soc., 101, 193-202, 1975.

Chevallier, F., et al.: $\mathrm{CO}_{2}$ surface fluxes at grid point scale estimated from a global 21 year reanalysis of atmospheric measurements, $\mathrm{J}$. Geophys. Res., 115, D21307, doi:10.1029/2010JD013887, 2010.

Ciais, P., et al.: Carbon and other biogeochemical cycles, in: Climate Change 2013: The Physical Science Basis. Contribution of Working Group I to the Fifth Assessment Report of the Intergovernmental Panel on Climate Change (final draft), IPCC working group I, http://www.climatechange2013. org/report/review-drafts/, 2013.

CIESIN: Gridded population of the world version 3(GPWv3): Population density grids, Technical report, Socioeconomic Data and Applications Center (SEDAC), Columbia University, Palisades, New York, USA, 2005.

Dai, A. G.: Precipitation Characteristics in Eighteen Coupled Climate Models, J. Climate, 19, 4605-4630, 2006. 
Delire, C., de Noblet-Ducoudré, N., Sima, A., and Gouirand, I.: Vegetation dynamics enhancing long-term climate variability confirmed by two models, J. Climate, 24, 2238-2257, 2011.

Denman, K. L., et al.: Couplings between changes in the climate system and biogeochemistry, in: Climate Change 2007: The Physical Science Basis. Contribution of Working Group I to the Fourth Assessment Report of the Intergovernmental Panel on Climate Change, edited by: Solomon, S., Qin, D., Manning, M., Chen, Z., Marquis, M., Averyt, K. B., Tignor, M., and Miller, H. L., Cambridge University Press, Cambridge, United Kingdom and New York, NY, USA, 996 pp., 2007.

Dickinson, R. E. and Kennedy P.: Impacts on regional climate of Amazon deforestation, Geophys. Res. Lett., 19, 1947-1950, 1992.

Duncan, B. N., Martin, R. V., Staudt, A. C., Yevich, R., and Logan, J. A.: Interannual and seasonal variability of biomass burning emissions constrained by satellite observations, J. Geophys.Res., 108, 4100, doi:10.1029/2002JD002378, 2003.

Ferretti, D. F., Miller, J. B., White, J. W. C., Etheridge, D.M., Lassey, K. R., Lowe, D. C., MacFarling Meure, C. M., Dreier, M. F., Trudinger, C. M., van Ommen, T. D., and Langenfelds, R. L.: Unexpected changes to the global methane budget over the past 2000 years, Science, 309, 1714-1717, 2005.

Fosberg, M. A., Cramer, W., Brovkin, V., Fleming, R., Gardner, R., Gill, A.M., Goldammer, J. G., Keane, R., Koehler, P., Lenihan, J., Neilson, R., Sitch, S., Thonicke, K., Venevski, S., Weber, M. G., and Wittenberg, U.: Strategy for a fire module in dynamic global vegetation models, Int. J. Wildland Fire, 9, 79-84, 1999.

Giglio, L., Kendall, J. D., and Mack, R.: A multi-year active fire data set for the tropics derived from the TRMM VIRS, Int. J. Remote Sens., 24, 4505-4525, 2003.

Giglio, L., Randerson, J. T., van der Werf, G. R., Kasibhatla, P. S., Collatz, G. J., Morton, D. C., and DeFries, R. S.: Assessing variability and long-term trends in burned area by merging multiple satellite fire products, Biogeosciences, 7, 1171-1186, doi:10.5194/bg-7-1171-2010, 2010.

Goulden, M. L., Winston, G. C., McMillan, A. M. S., Litvak, M. E., Read, E. L., Rocha, A. V., and Elliot, J. R.: An eddy covariance mesonet to measure the effect of forest age on land-atmosphere exchange, Glob. Change Biol., 12, 2146-2162, 2006.

Grégoire, J.-M., Tansey, K., and Silva, J. M. N.: The GBA2000 initiative: developing a global burned area database from SPOTVEGETATION imagery. Int. J. Remote Sens., 24, 1369-1376, 2003.

Guenther, A. B., Jiang, X., Heald, C. L., Sakulyanontvittaya, T., Duhl, T., Emmons, L. K., and Wang, X.: The Model of Emissions of Gases and Aerosols from Nature version 2.1 (MEGAN2.1): an extended and updated framework for modeling biogenic emissions, Geosci. Model Dev., 5, 1471-1492, 2012.

Hegerl, G. C., Zwiers, F. W., Braconnot, P., Gillett, N. P., Luo, Y., Marengo Orsini, J. A., Nicholls, N., Penner, J. E., and Stott, P. A.: Understanding and Attributing Climate Change, in: Climate Change 2007: The Physical Science Basis. Contribution of Working Group I to the Fourth Assessment Report of the Intergovernmental Panel on Climate Change, Solomon, S., D. Qin, M. Manning, Z. Chen, M. Marquis, K.B. Averyt, M. Tignor and H.L. Miller (eds.), Cambridge University Press, Cambridge, United Kingdom and New York, NY, USA, 2007.
Hicke, J. A., Asner, G. P., Kasischke, E. S., French, N. H. F., Randerson, J. T., Collatz, G., J., Stocks, B. J., Tucker, C. J., Los, S. O., and Field, C. B.: Postfire response of North American boreal forest net primary productivity analyzed with satellite observations, Glob. Change Biol., 9, 1145-1157, 2003.

Houghton, R. A.: The annual net flux of carbon to the atmosphere from changes in land use 1850-1990, Tellus, 51B, 298-313, 1999.

Houghton, R. A.: Revised estimates of the annual net flux of carbon to the atmosphere from changes in land use and land management 1850-2000, Tellus B, 55, 378-390, 2003.

Houghton, R. A., Hackler, J. L., and Lawrence, K. T.: Changes in terrestrial carbon storage in the United States. 2: The role of fire and fire management, Global Ecol. Biogeogr., 9, 145-170, 2000.

Hurrel, J. W., et al.: The Community Earth System Model: a framework for collaborative research, B. Am. Meteorol. Soc., 94, 1339-1360, 2013.

Hurtt, G. C., Frolking, S., Fearon, M. G., Moore, B., Shevliakova, E., Malyshev, S., Pacala, S. W., and Houghton, R. A.: The underpinnings of land-use history: three centuries of global gridded land-use transitions, wood-harvest activity, and resulting secondary lands, Glob. Change Biol., 12, 1208-1229, 2006.

Irvine, J., Law, B. E., and Hibbard, K. A.: Postfire carbon pools and fluxes in semiarid ponderosa pine in Central Oregon, Glob. Change Biol., 13, 1748-1760, 2007.

Jacobson, M. Z.: The short-term cooling but long-term global warming due to biomass burning, J. Climate, 17, 2909-2926, 2004.

Joetzjer, E., Douville, H., Delire, C., and Ciais, P.: Present-day and future Amazonian precipitation in global climate models: CMIP5 versus CMIP3, Clim. Dynam., 41, 2921-2936, doi:10.1007/s00382-012-1644-1, 2013.

Jung, M., et al.: Global patterns of land-atmosphere fluxes of carbon dioxide, latent heat, and sensible heat derived from eddy covariance, satellite, and meteorological observations, J. Geophys. Res., 116, G00J07, doi:10.1029/2010jg001566, 2011.

Kasischke, E. S., Christensen, N. L., Jr., and Stocks, B. J.: Fire, global warming, and the carbon balance of boreal forests, Ecol. Appl., 5, 437-451, 1995.

Klein Goldewijk, K., Beusen, A., and Janssen, P.: Long term dynamic modeling of global population and built-up area in a spatially explicit way, HYDE 3 1, The Holocene, 20, 565-573, 2010.

Kloster, S., Mahowald, N. M., Randerson, J. T., Thornton, P. E., Hoffman, F. M., Levis, S., Lawrence, P. J., Feddema, J. J., Oleson, K. W., and Lawrence, D. M.: Fire dynamics during the 20th century simulated by the Community Land Model, Biogeosciences, 7, 1877-1902, doi:10.5194/bg-7-1877-2010, 2010.

Koven, C. D., Riley, W. J., Subin, Z. M., Tang, J. Y., Torn, M. S., Collins, W. D., Bonan, G. B., Lawrence, D. M., and Swenson, S. C.: The effect of vertically-resolved soil biogeochemistry and alternate soil $\mathrm{C}$ and $\mathrm{N}$ models on C dynamics of CLM4, Biogeosciences Discuss., 10, 7201-7256, doi:10.5194/bgd-10-72012013, 2013.

Law, B. E., Sun, O. J., Campbell, J., Van Tuyl, S., and Thornton, P. E.: Changes in carbon storage and fluxes in a chronosequence of ponderosa pine, Glob. Change Biol., 9, 510-524, 2003.

Lawrence, D., Oleson, K. W., Flanner, M. G., Thorton, P. E., Swenson, S. C., Lawrence, P. J., Zeng, X., Yang, Z. L., Levis, S., Skaguchi, K., Bonan, G. B., and Slater, A. G.: Parameterization Im- 
provements and Functional and Structural Advances in Version 4 of the Community Land Model, J. Adv. Model. Earth Syst., 3, M03001, 27 pp., 2011.

Lawrence, P. J., et al.: Simulating the biogeochemical and biogeophysical impacts of transient land cover change and wood harvest in the Community Climate System Model (CCSM4) from 1850 to 2100, J. Climate, 25, 3071-3095, 2012.

Le Quéré, C., et al.: The global carbon budget 1959-2011, Earth Syst. Sci. Data Discuss., 5, 1107-1157, doi:10.5194/essdd-51107-2012, 2012.

Levis, S., Foley, J. A., Brovkin, V., and Pollard, D.: On the stability of the high-latitude climate-vegetation system in a coupled atmosphere-biosphere model, Glob. Ecol. Biogeogr., 8, 489-500, 1999.

Levis, S., Bonan, G. B., and Bonfils, C.: Soil feedback drives the Mid-Holocene North African monsoon northward in fully coupled CCSM2 simulations with a dynamic vegetation model, Climate Dyn., 23, 791-802, 2004a.

Levis, S., Bonan, G. B., Vertenstein, M., and Oleson, K. W.: The Community Land Model's dynamic global vegetation model (CLM-DGVM): Technical description and user's guide, NCAR Tech. Note TN-459 IA, Terrestrial Sciences Section, Boulder, Colorado, 2004b.

Li, F., Zeng, X.-D., and Levis, S.: A process-based fire parameterization of intermediate complexity in a Dynamic Global Vegetation Model, Biogeosciences, 9, 2761-2780, 2012a, http://www.biogeosciences.net/9/2761/2012/.

Li, F., Zeng, X.-D., and Levis, S.: Corrigendum to "A process-based fire parameterization of intermediate complexity in a Dynamic Global Vegetation Model" published in Biogeosciences, 9, 27612780, 2012, Biogeosciences, 9, 4771-4772, doi:10.5194/bg-94771-2012, 2012b.

Li, F., Levis, S., and Ward, D. S.: Quantifying the role of fire in the Earth system - Part 1: Improved global fire modeling in the Community Earth System Model (CESM1), Biogeosciences, 10, 2293-2314, doi:10.5194/bg-10-2293-2013, 2013.

Mao, J.-F., Thornton, P. E., Shi, X.-Y., Zhao, M.-S., and Post, W. M.: Remote Sensing Evaluation of CLM4 GPP for the Period 2000-09, J. Climate, 25, 5327-5342, 10.1175/JCLI-D-1100401.1, 2012.

Marlon, J. R., Bartlein, P. J., Carcaillet, C., Gavin, D. G., Harrison, S. P., Higuera, P. E., Joos, F., Power, M. J., and Prentice, I. C.: Climate and human influences on global biomass burning over the past two millennia, Nat. Geosci., 1, 697-702, 2008.

Marlon, J. R., Bartlein, P. J., Daniau, A. L., Harrison, S. P., Power, M.J., Tinner, W., Maezumie, S., and Vanniére, B.: Global biomass burning: a synthesis and review of holocene paleofire records and their controls, Quaternary Sci. Rev., 65, 5-25, 2013.

Mieville, A., Granier, C., Liousse, C., Guillaume, B., Mouillot, F., Lamarque, J.-F., Gregoire, J. M., and Petron, G.: Emissions of gases and particles from biomass burning during the 20th century using satellite data and an historical reconstruction, Atmos. Environ., 44, 1469-1477, 2010.

Mouillot, F., Narasimha, A., Balkanski, Y., Lamarque, J. F., and Field, C. B.: Global carbon emissions from biomass burning in the 20th century, Geophys. Res. Lett., 33, L01801, doi:10.1029/2005GL024707, 2006.
Murphy, B. P. and Bowman, D. M. J. S.: What controls the distribution of tropical forest and savanna?, Ecol. Lett., 15, 748-758, 2012

Oleson, K. W., Lawrence, D. M., Bonan, G. B., Drewniak, B., Huang, M., Koven, C. D., Levis, S., Li, F., Riley, W. J., Subin, Z. M., Swenson, S. C., Thornton, P. E., Bozbiyik, A., Fisher, R., Heald, C. L., Kluzek, E., Lamarque, J.-F., Lawrence, P. J., Leung, L. R., Lipscomb, W., Muszala, S., Ricciuto, D. M., Sacks, W., Sun, Y., Tang, J., and Yang, Z.-L.: Technical description of version 4.5 of the Community Land Model (CLM), NCAR Technical Note NCAR/TN-503+STR, 434 pp., 2013.

Piao, S., et al.: Evaluation of terrestrial carbon cycle models for their response to climate variability and to $\mathrm{CO}_{2}$ trends, Glob. Change Biol., 19, 2117-2132, 2013.

Prentice, I. C.: The burning issue, Sciences, 330, 1636-1637, 2010.

Prentice, I. C., Kelley, D. I., Foster, P. N., Friedlingstein, P., Harrison, S. P., and Bartlein, P. J.: Modeling fire and the terrestrial carbon balance, Global Biogeochem. Cy., 25, GB3005, doi:10.1029/2010GB003906, 2011.

Prentice, S. A. and Mackerras, D.: The ratio of cloud to cloudground lightning flashes in thunderstorms, J. Appl. Meteorol., 16, 545-550, 1977.

Qian, T., Dai, A., Trenberth, K. E., and Oleson, K. W.: Simulation of global land surface conditions from 1948 to 2004. Part I: Forcing data and evaluations, J. Hydrometeorol., 7, 953-975, 2006.

Randerson, J. T., Chapin, F. S., Harden, J., Neff, J. C., and Harmon, M.: Net ecosystem production: a comprehensive measure of net carbon accumulation by ecosystems, Ecol. Appl., 12, 937-947, 2002.

Randerson, J. T., et al.: The impact of boreal forest fire on climate warming, Science, 314, 1130-1132, doi:10.1126/science.1132075, 2006.

Randerson, J. T., Chen, Y., van der Werf, G. R., Rogers, B. M., and Morton, D.: Small fire contributions to global burned area and biomass burning emissions, J. Geophys. Res., 117, G04012, doi:10.1029/2012JG002128, 2012.

Rödenbeck, C., Conway, T. J., and Langenfelds, R. L.: The effect of systematic measurement errors on atmospheric $\mathrm{CO}_{2}$ inversions: a quantitative assessment, Atmos. Chem. Phys., 6, 149-161, 2006, http://www.atmos-chem-phys.net/6/149/2006/.

Roy, D. P., Jin, Y., Lewis, P. E., and Justice, C. O.: Prototyping a global algorithm for systematic fire-affected area mapping using MODIS time series data, Remote Sens. Environ., 97, 137-162, 2005.

Running, S. W.: Ecosystem disturbance, carbon, and climate, Science, 321, 652-653, 2008.

Sanjiv, K., Merwade, V., Kinter, J. L., and Niyogi, D.: Evaluation of Temperature and Precipitation Trends and Long-Term Persistence in CMIP5 Twentieth-Century Climate Simulations, J. Climate, 26, 4168-4185, 2013.

San José, J. J., Montes, R. A., and Farinas, M. R.: Carbon stocks and fluxes in a temporal scaling from a savanna to a semi-deciduous forest, Forest Ecol. Manag., 105, 251-262, 1998.

Scheiter, S. and Higgins, S. I.: Impacts of climate change on the vegetation Africa: an adaptive dynamic vegetation modeling approach, Glob. Change Biol., 15, 2224-2246, 2009.

Schulze, E. D.: Biological control of the terrestrial carbon sink, Biogeosciences, 3, 147-166, doi:10.5194/bg-3-147-2006, 2006 
Schultz, M. G.: On the use of ATSR fire count data to estimate the seasonal and interannual variability of vegetation fire emissions, Atmos. Chem. Phys., 2, 387-395, doi:10.5194/acp-2-387-2002, 2002.

Schultz, M. G., Heil, A., Hoelzemann, J. J., Spessa, A., Thonicke, K., Goldammer, J. G., Held, A. C., Pereira, J. M. C., and van het Bolscher, M.: Global wildland fire emissions from 1960 to 2000, Global Biogeochem. Cy., 22, GB2002, doi:10.1029/2007GB003031, 2008.

Seiler, W. and Crutzen, P. J.: Estimates of gross and net fluxes of carbon between the biosphere and atmosphere from biomass burning, Clim. Change, 2, 207-247, 1980.

Shackleton, C. M. and Scholes, R. J.: Impact of fire frequency on woody community structure and soil nutrients in the Kruger National Park, Koedoe, 43, 75-81, 2000.

Sitch, S., Smith, B., Prentice, I. C., Arneth, A., Bondeau, A., Cramer, W., Kaplan, J. O., Levis, S., Lucht, W., Sykes, M. T., Thonicke, K., and Venevsky, S.: Evaluation of ecosystem dynamics, plant geography and terrestrial carbon cycling in the LPJ dynamic global vegetation model, Glob. Change Biol., 9, 161-185, 2003.

Soja, A. J., Cofer, W. R., Shugart, H. H., Sukhinin, A. I., Stackhouse, P. W., McRae, D. J., and Conard, S. G.: Estimating fire emissions and disparities in boreal Siberia (1998-2002), J. Geophys. Res., 109, D14S06, doi:10.1029/2004JD004570, 2004.

Staver, A. C., Archibald, S., and Levin, S. A., The global extent and determinants of savanna and forest as alternative biome states, Science, 334, 230-232, 2011

Subin, Z. M., Riley, W. J., and Mironov, D.: Improved lake model for climate simulations, J. Adv. Model. Earth Syst., 4, M02001, doi:10.1029/2011MS000072, 2012.

Sun, Y., Gu, L., and Dickinson, R. E.: A numerical issue in calculating the coupled carbon and water fluxes in a climate model, J. Geophys. Res., 117, D22103, doi:10.1029/2012JD018059, 2012.

Swenson, S. C. and Lawrence, D. M.: A New Fractional Snow Covered Area Parameterization for the Community Land Model and its Effect on the Surface Energy Balance, J. Geophys. Res., 117, D21107, doi:10.1029/2012JD018178, 2012.

Swenson, S. C., Lawrence, D. M., and Lee, H.: Improved Simulation of the Terrestrial Hydrological Cycle in Permafrost Regions by the Community Land Model, J. Adv. Model. Earth Syst., 4, M08002, doi:10.1029/2012MS000165, 2012.

Thonicke, K. Spessa, A., Prentice, I. C., Harrison, S. P., Dong, L., and Carmona-Moreno, C.: The influence of vegetation, fire spread and fire behaviour on biomass burning and trace gas emissions: results from a process-based model, Biogeosciences, 7, 1991-2011, doi:10.5194/bg-7-1991-2010, 2010.

Thornton, P. E., Law, B., Gholz, H., Clark, K., Falge, E., Ellsworth, D., Goldstein, A., Monson, R., Hollinger, D., and Falk, M.: Modeling and measuring the effects of disturbance history and climate on carbon and water budgets in evergreen needleleaf forests, Agr. Forest Meteorol., 113, 185-222, 2002.

Thornton, P. E., Lamarque, J., Rosenbloom, N., and Mahowald, N. M.: Influence of carbon-nitrogen cycle coupling on land model response to $\mathrm{CO} 2$ fertilization and climate variability, Global Biogeochem. Cy., 21, GB4018, doi:10.1029/2006GB002868, 2007.

Tilman, D., Reich, P., Phillips, H., Menton, M., Patel, A., Vos, E., Peterson, D., and Knops, J.: Fire suppression and ecosystem carbon storage, Ecology, 81, 2680-2685, 2000. van der Werf, G. R., Randerson, J. T., Giglio, L., Collatz, G. J., Kasibhatla, P. S., and Arellano Jr, A. F.: Interannual variability in global biomass burning emissions from 1997 to 2004, Atmos. Chem. Phys., 6, 3423-3441, 2006,

http://www.atmos-chem-phys.net/6/3423/2006/.

van der Werf, G. R., Randerson, J. T., Giglio, L., Collatz, G. J., Mu, M., Kasibhatla, P. S., Morton, D. C., DeFries, R. S., Jin, Y., and van Leeuwen, T. T.: Global fire emissions and the contribution of deforestation, savanna, forest, agricultural, and peat fires (19972009), Atmos. Chem. Phys., 10, 11707-11735, doi:10.5194/acp10-11707-2010, 2010.

van der Werf, G. R., Peters, W., van Leeuwen, T. T., and Giglio, L.: What could have caused pre-industrial biomass burning emissions to exceed current rates?, Clim. Past, 9, 289-306, 2013, http://www.clim-past.net/9/289/2013/.

Wang, C. K., Gower S. T., Wang Y. H., Zhao, H. X., Yan, P., and Bond-Lamberty, B.: The influence of fire on carbon distribution and net primary production of boreal Larixgmelinii forests in north-eastern China, Glob. Change Biol., 7, 719-730, 2001.

Wang, Z., Chappellaz, J., Park, K., and Mark, J. E.: Large variations in Southern Hemisphere biomass burning during the last 650 years, Science, 330, 1663-1666, 2010.

Ward, D. S., Kloster, S., Mahowald, N. M., Rogers, B. M., Randerson, J. T., and Hess, P. G.: The changing radiative forcing of fires: global model estimates for past, present and future, Atmos. Chem. Phys., 12, 10857-10886, doi:10.5194/acp12-10857-2012, 2012.

Weir, J. R.: Using relative humidity to predict spotfire probability on prescribed burns, in: Proceedings: Shrubland dynamics - fire and water, edited by: Sosebee, R. E, Wester, D. B.; Britton, C. M., McArthur, E. D., Kitchen, S. G., Proceedings RMRS-P-47, US Department of Agriculture, Forest Service, Rocky Mountain Research Station, 69-72, 2007.

Williams, R. J., Gill, A. M., and Moore, P. H. R.: Seasonal changes in fire behaviour in a tropical Savanna in Northern Australia, Int. J. Wildland Fire, 8, 227-239, 1998.

Yi, Y., Kimball, J. S., Jones, L. A., Reichle, R. H., Nemani, R., and Margolis, H. A.: Recent climate and fire disturbance impacts on boreal and arctic ecosystem productivity estimated using a satellite-based terrestrial carbon flux model, J. Geophys. Res., 118, 606-622, 2013.

Yue, C., Ciais, P., Luyssaert, S., Cadule, P., Harden, J., Randerson, J., Bellassen, V., Wang, T., Piao, S. L., Poulter, B., and Viovy, N.: Simulating boreal forest carbon dynamics after stand-replacing fire disturbance: insights from a global processbased vegetation model, Biogeosciences Discuss., 10, 72997366, doi:10.5194/bgd-10-7299-2013, 2013.

Zeng, X.-D., Li, F., and Song, X.: Development of the IAP Dynamic Global Vegetation Model, Adv. Atmos. Sci., in press, doi:10.1007/s00376-013-3155-3, 2014.

Zhao, M. and Running, S. W.: Drought-induced reduction in global terrestrial net primary production from 2000 through 2009, Science, 329, 940-943, 2010.

Zhao, M., Running, S. W., and Nemani, R. R.: Sensitivity of Moderate Resolution Imaging Spectroradiometer (MODIS) terrestrial primary production to the accuracy of meteorological reanalyses, J. Geophys. Res., 111, G01002, doi:10.1029/2004JG000004, 2006. 